\title{
Fire Protection Systems Evaluation Office Building
}

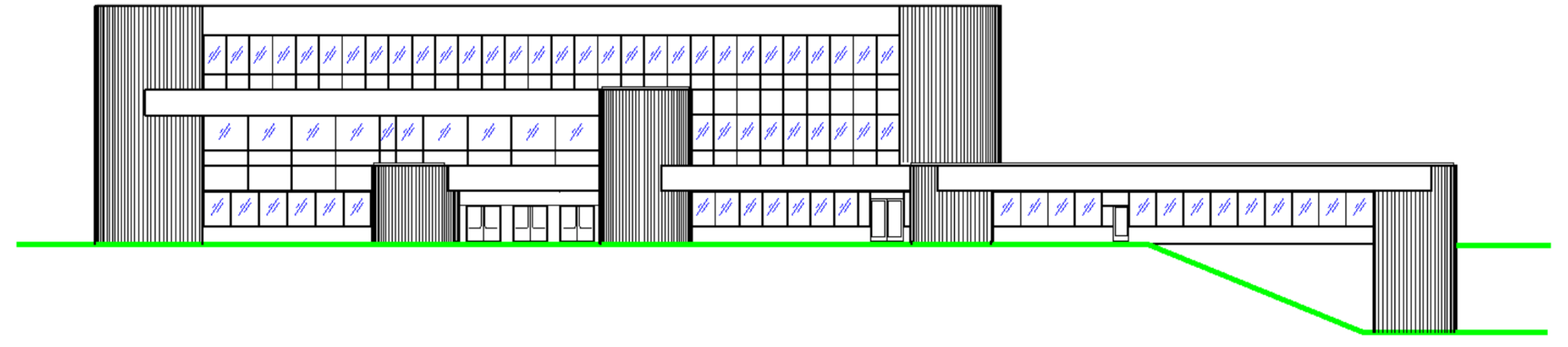

Christine Newton 


\section{Agenda}

- Prescriptive-based Evaluation

- Building Overview

- Structure

- Occupancy

- Egress

- Detection and Suppression Systems

- Performance-based Evaluation

- Fire Scenario 1

- Fire Scenario 2 


\section{Building Overview}

- Completed in 1991

- 107,500 square feet total

- Four Story Building

- 3 above ground floors

- Basement with exterior access

- 16' between floors

- $8^{\prime}-10^{\prime}$ ceilings with space above ceiling used for services conveyance

- Mostly Office Space

- Automatic Wet Sprinkler System

- Fire Alarm and Detection System 


\section{Building Layout - Basement}

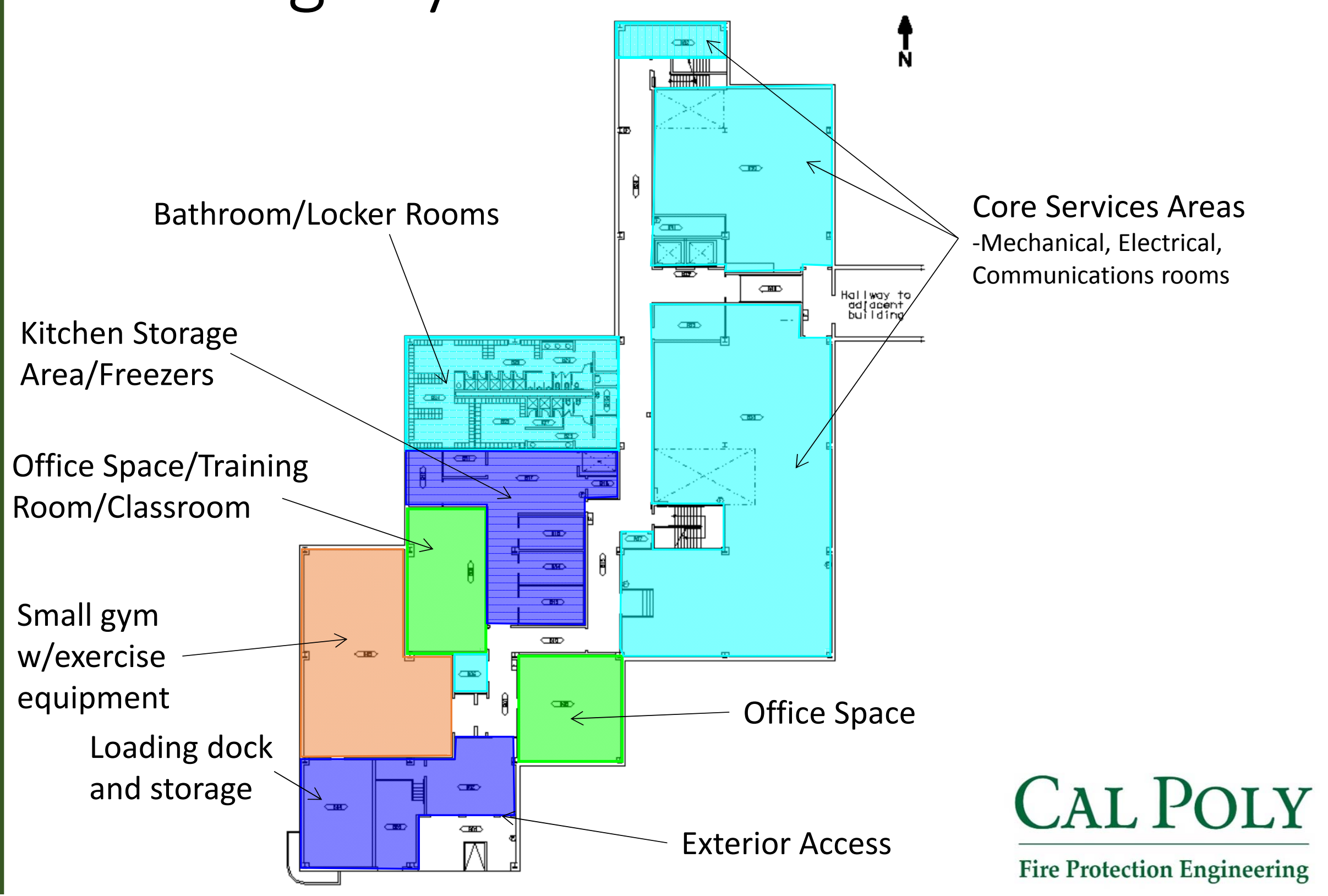




\section{Building Layout - First Floor}

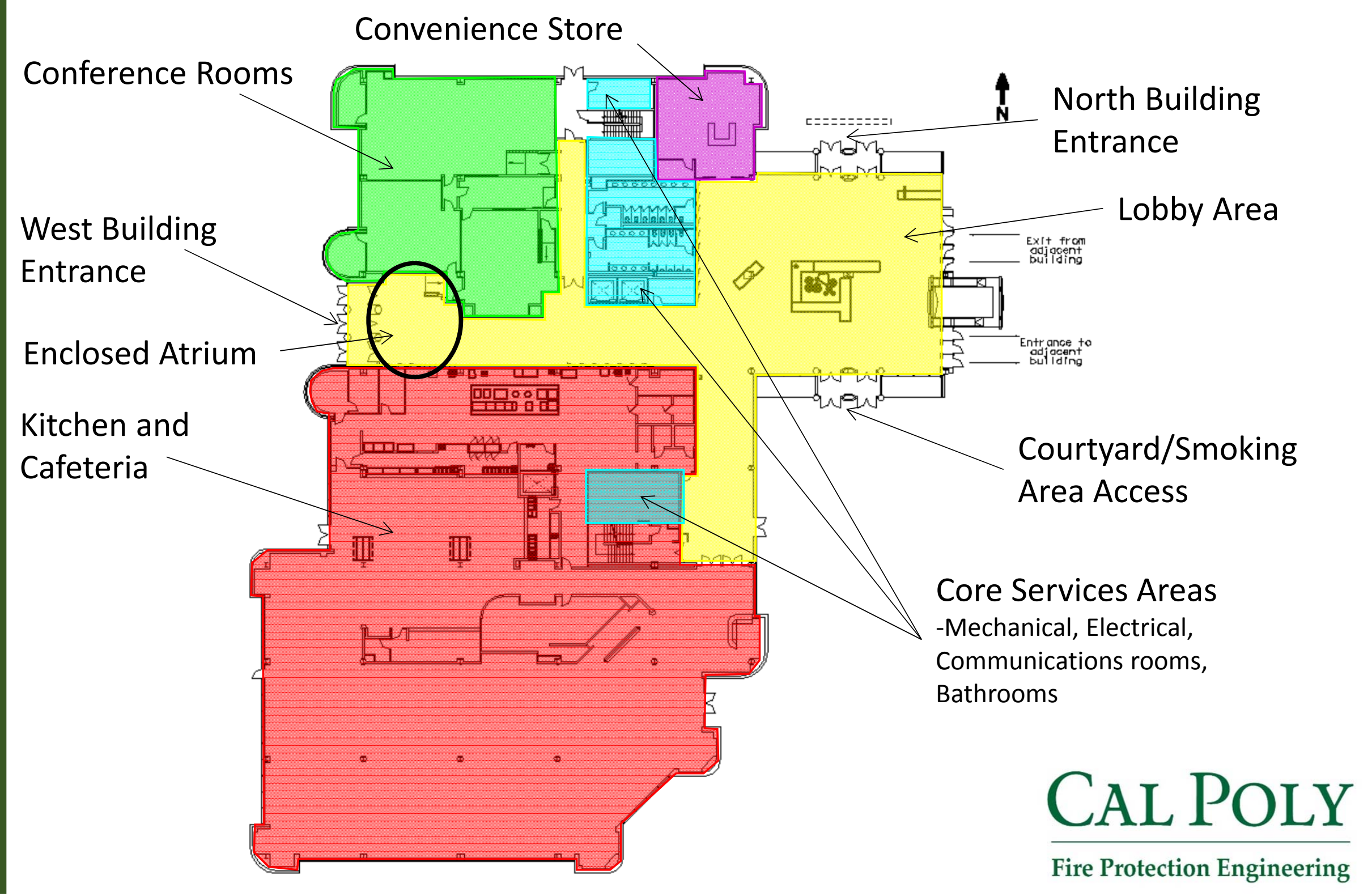




\section{Building Layout - Second Floor}

Conference Rooms, Offices, Cubicle Space

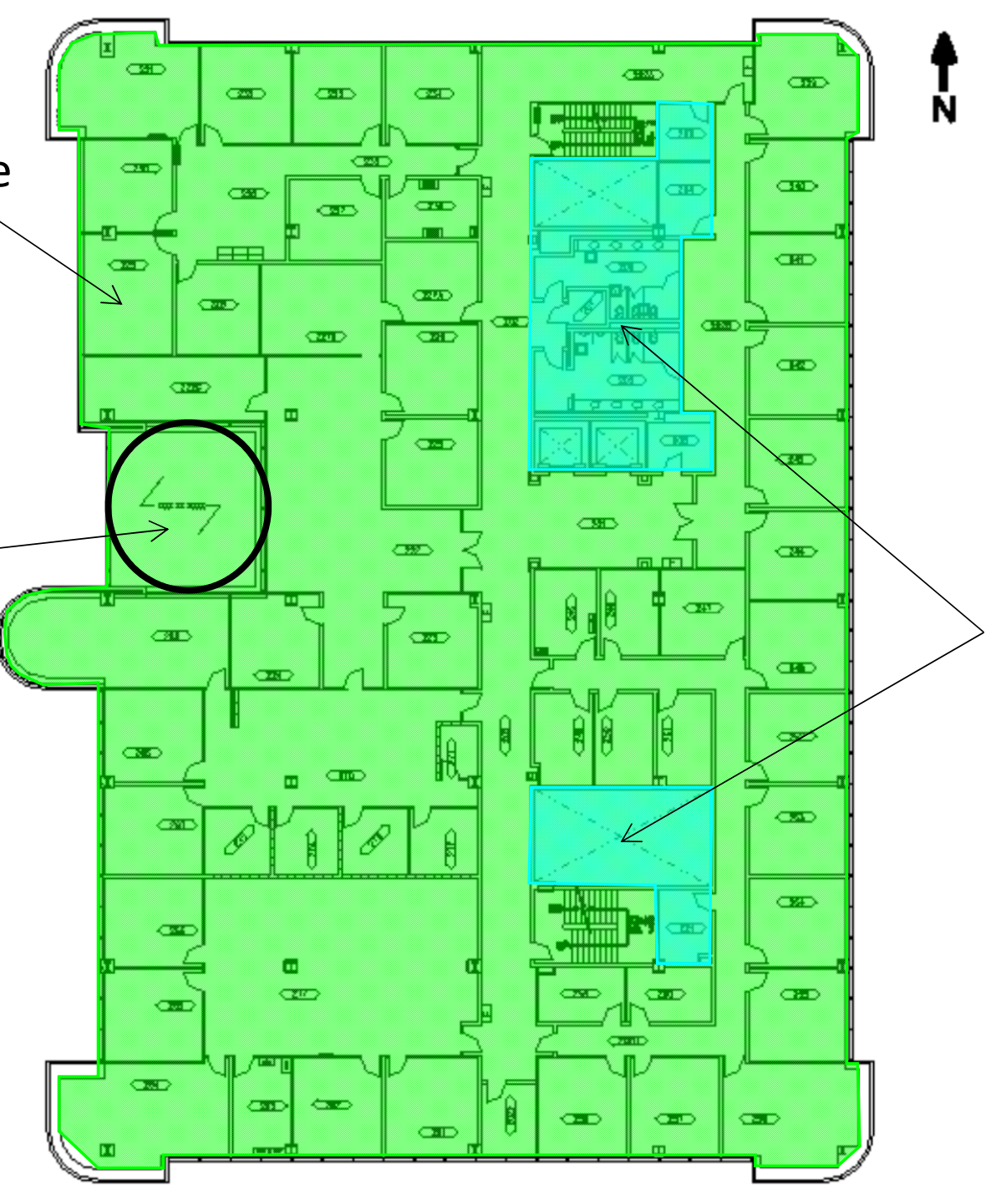

Core Services Areas -Mechanical, Electrical, Communications rooms, Bathrooms

\section{Cal Poly}

Fire Protection Engineering 


\section{Building Layout - Third Floor}

Conference Rooms, Offices, Cubicle Space

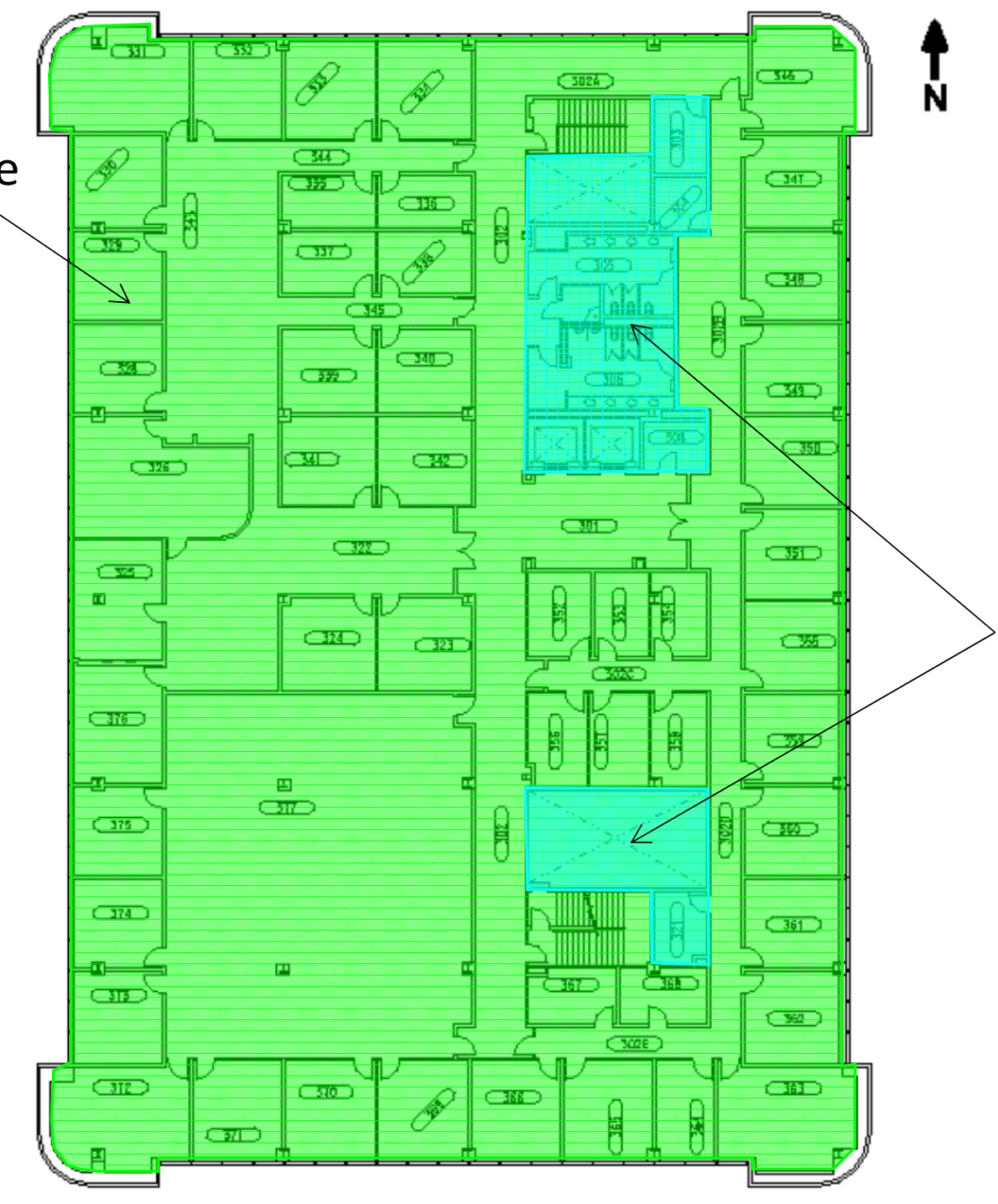

Core Services Areas -Mechanical, Electrical, Communications rooms, Bathrooms 


\section{Structure}

Building Occupancy Classification

- Mixed Occupancy Building

- Main Occupancy is Group B

\begin{tabular}{l|c|c|}
\hline USE OF AREA & OCCUPANCY CLASSIFICATION & FLOOR \\
\hline $\begin{array}{l}\text { Offices, Conference Rooms, } \\
\text { Training Rooms }\end{array}$ & Business - Group B & All \\
\hline $\begin{array}{l}\text { Convenience Store } \\
\text { Kitchen \& Cafeteria }\end{array}$ & Mercantile - Group M & First \\
\hline $\begin{array}{l}\text { Gym/Fitness Room } \\
\text { Storage Rooms, Loading } \\
\text { Dock }\end{array}$ & Accessory to Business - Group B & First \\
\hline $\begin{array}{l}\text { Mechanical/Electrical/Equi } \\
\text { pment Rooms }\end{array}$ & Accessory to Business - Group B & Basement \\
\hline
\end{tabular}




\section{Structure}

\section{Construction Type}

Table 503- 2012 IBC

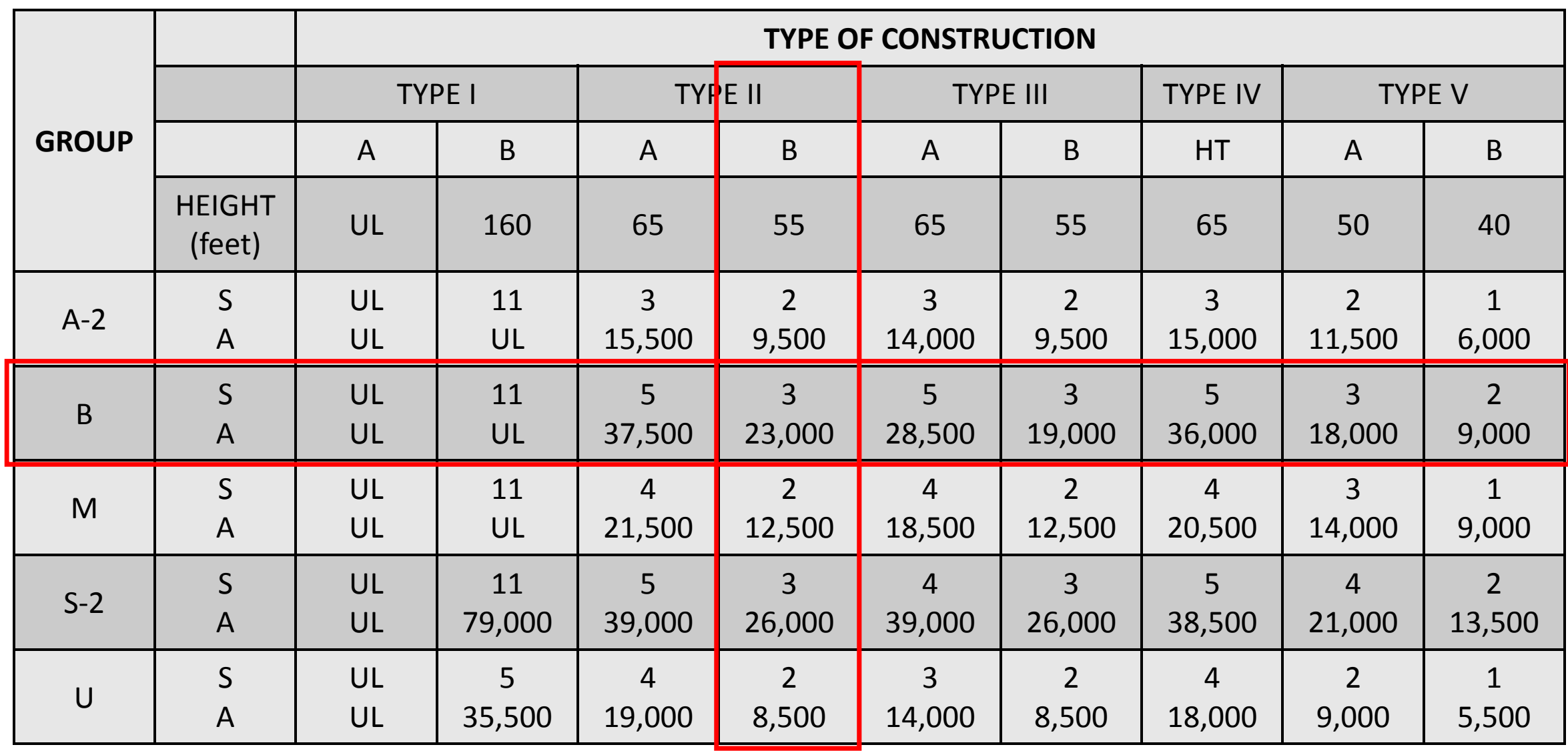




\section{Structure}

Building Elements

- Foundation

- 6" concrete slab

- Primary Steel Support

- Wide-flange columns, beams, girders, and joists

- Floor/Roof Assemblies

- 16 or 18 gauge metal deck with $2.5^{\prime \prime}, 4$ ", or 5" concrete reinforced with welded-wire fabric

- Exterior Walls

- Precast concrete panels supported with wide-flange steel beams

- Interior Walls

- 3-5/8" steel studs @ 16" on-center with type x gypsum wall board on each side 


\section{Occupancy}

Occupant Loads - Basement

\begin{tabular}{|l|c|}
\hline Occupancy & \multicolumn{1}{|c|}{$\begin{array}{c}\text { Calculated } \\
\text { Occupant Load }\end{array}$} \\
\hline Business & 19 \\
\hline $\begin{array}{l}\text { Exercise Rm } \\
\text { w/Equip }\end{array}$ & 42 \\
\hline Kitchen Storage & 19 \\
\hline $\begin{array}{l}\text { Accessory } \\
\text { (Mech/Elec/Comm } \\
\text { rms) }\end{array}$ & N/A \\
\hline Storage & N/A \\
\hline
\end{tabular}

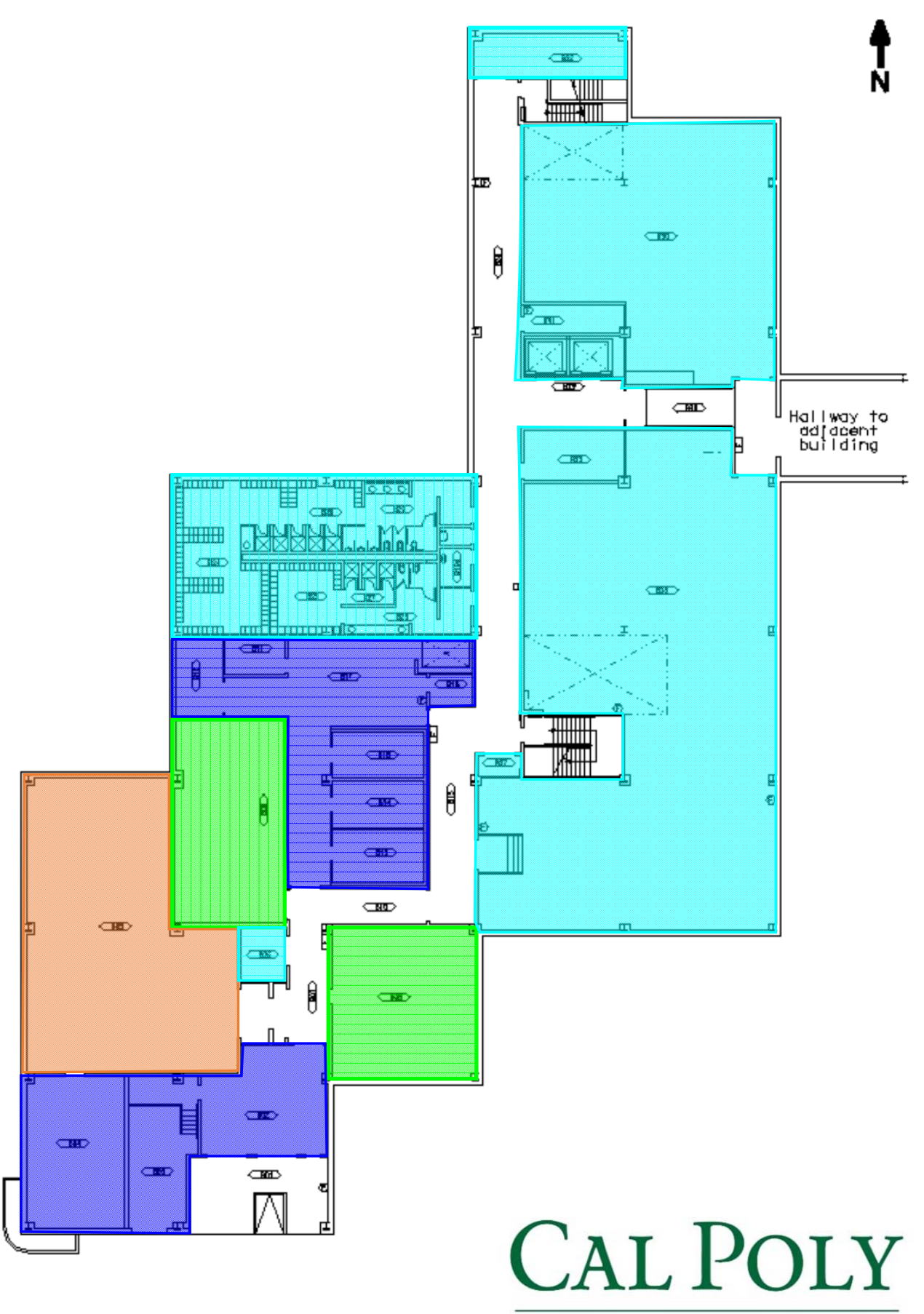

Fire Protection Engineering 


\section{Occupancy}

Occupant Loads - First Floor

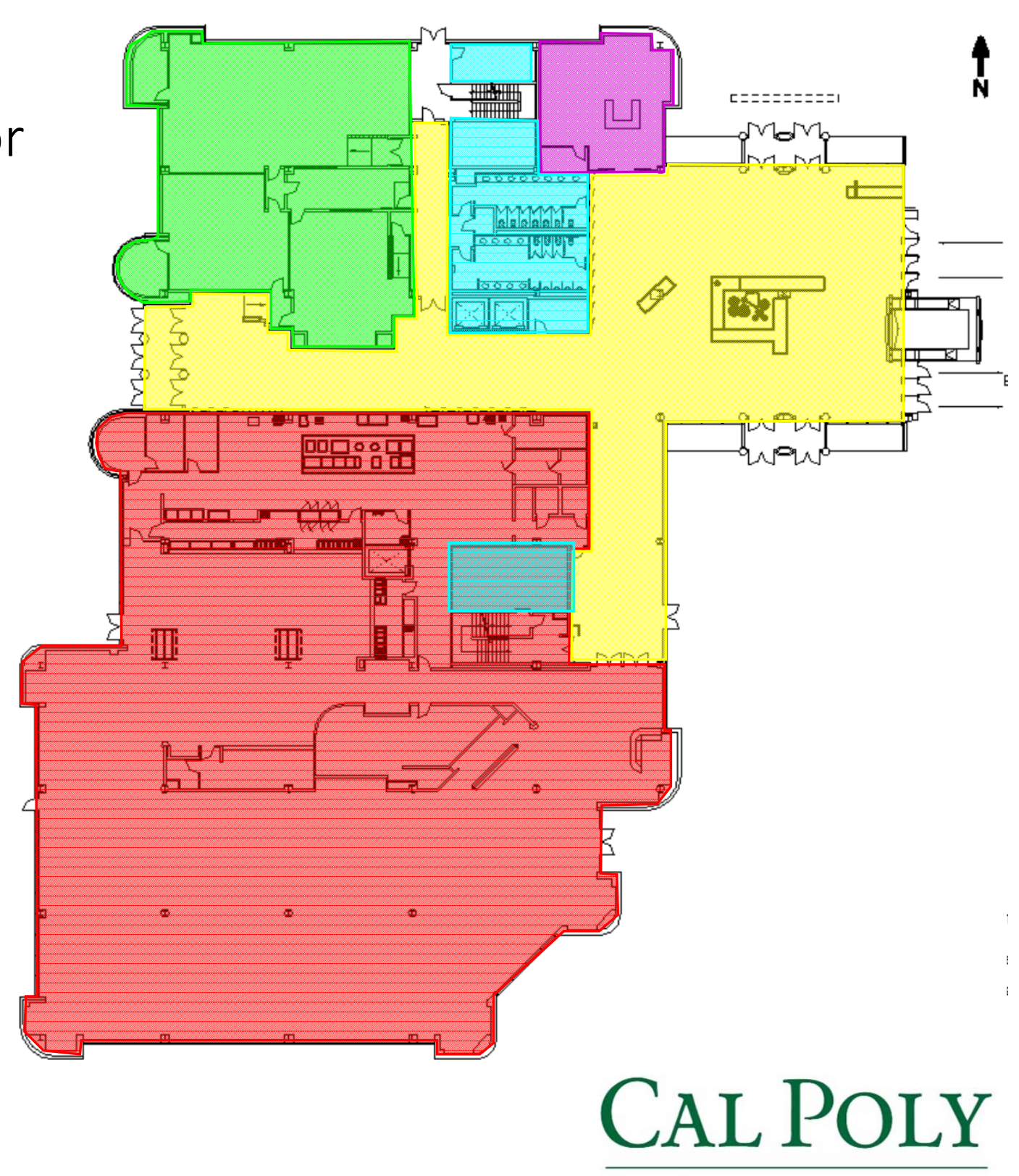

Fire Protection Engineering 


\section{Occupancy}

Occupant Loads - Second Floor

\begin{tabular}{l|c|}
\hline Occupancy & $\begin{array}{c}\text { Calculated } \\
\text { Occupant Load }\end{array}$ \\
\hline Business & 218 \\
\hline $\begin{array}{l}\text { Accessory } \\
\text { (Mech/Elec/Comm } \\
\text { rms) }\end{array}$ & N/A \\
\hline
\end{tabular}

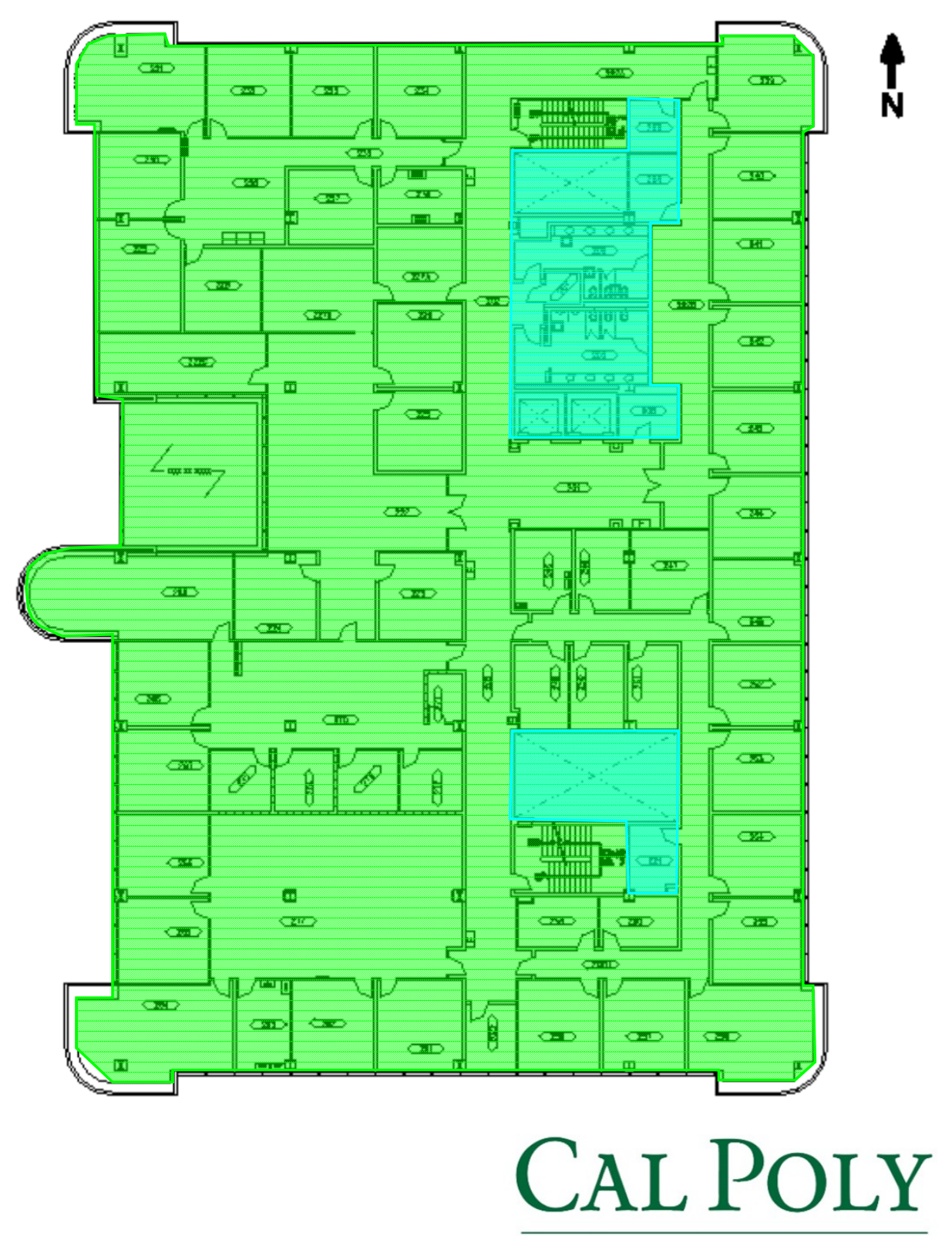

Fire Protection Engineering 


\section{Occupancy}

Occupant Loads - Third Floor

\begin{tabular}{|l|c|}
\hline Occupancy & $\begin{array}{c}\text { Calculated } \\
\text { Occupant Load }\end{array}$ \\
\hline Business & 224 \\
\hline $\begin{array}{l}\text { Accessory } \\
\text { (Mech/Elec/Comm } \\
\text { rms) }\end{array}$ & N/A \\
\hline
\end{tabular}

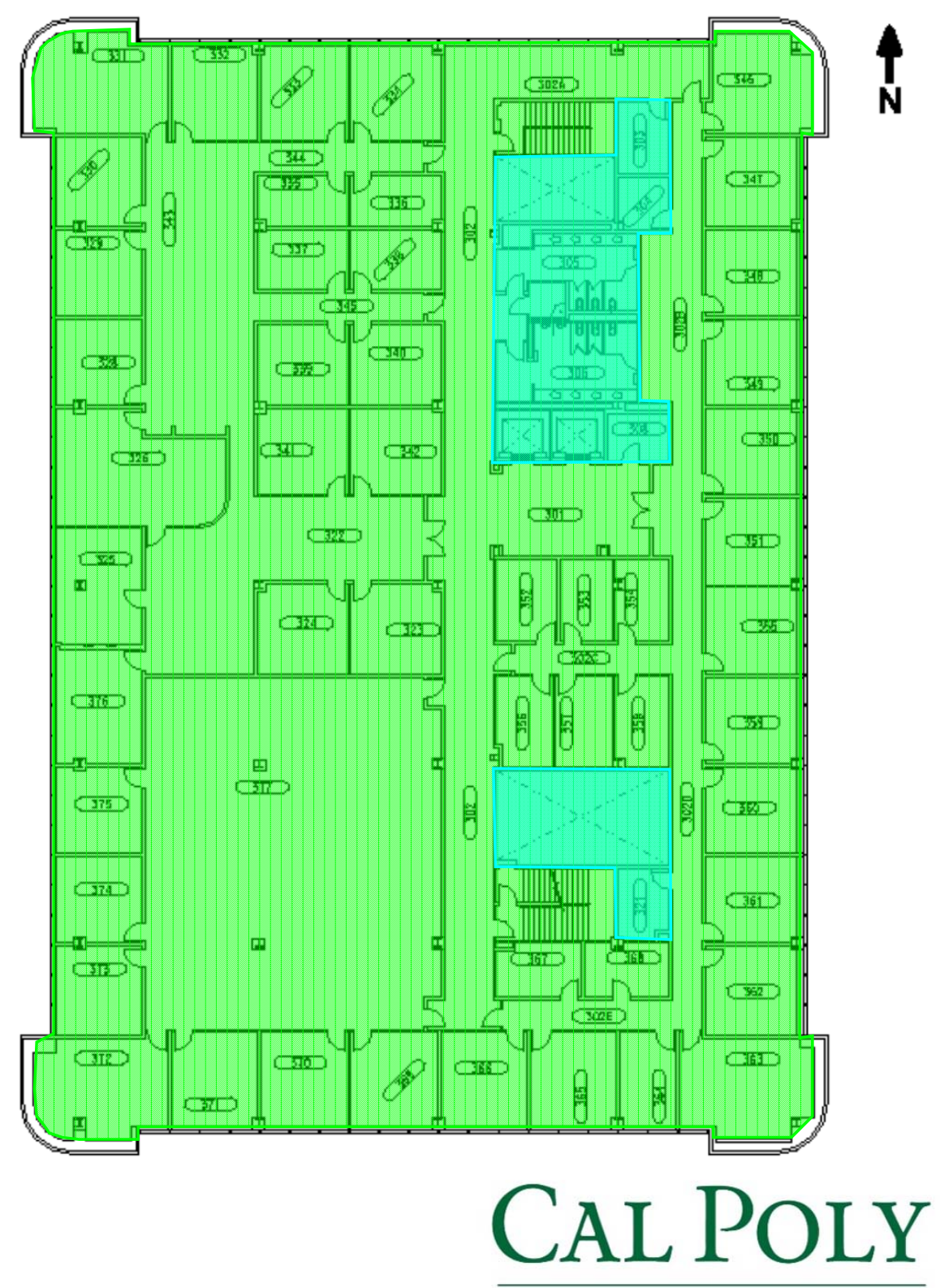

Fire Protection Engineering 


\section{Occupancy}

Occupant Loads Summary

\begin{tabular}{|l|c|}
\hline Building Floor & $\begin{array}{c}\text { Calculated Occupant } \\
\text { Load }\end{array}$ \\
\hline Basement & 80 \\
\hline First Floor & 698 \\
\hline Second Floor & 218 \\
\hline Third Floor & 224 \\
\hline Total & 1250 \\
\hline
\end{tabular}




\section{Egress}

Basement Exits

- Two stairways to the first floor

- One door to the exterior of the building

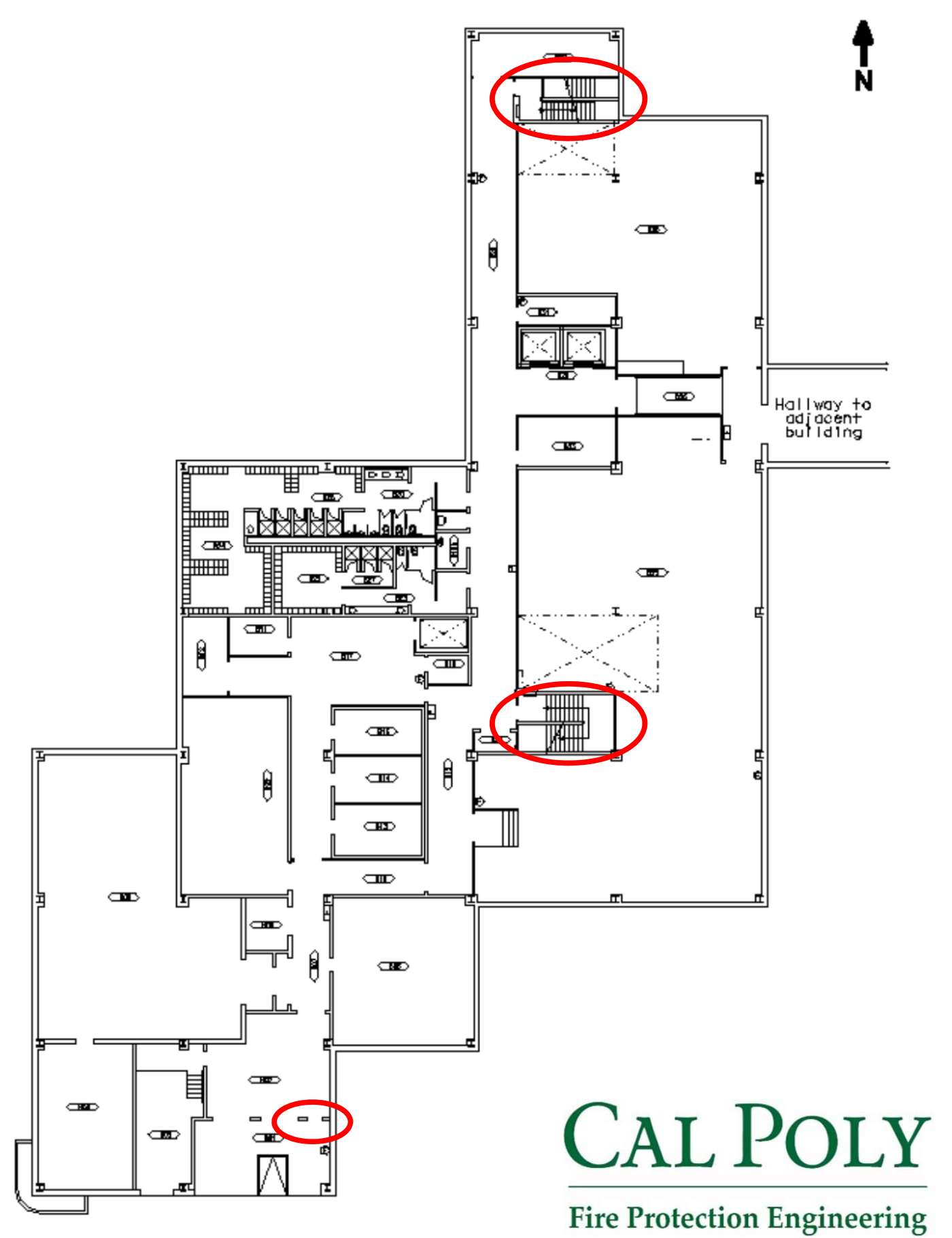


Egress

First Floor Exits

- Eight total exits from the first floor

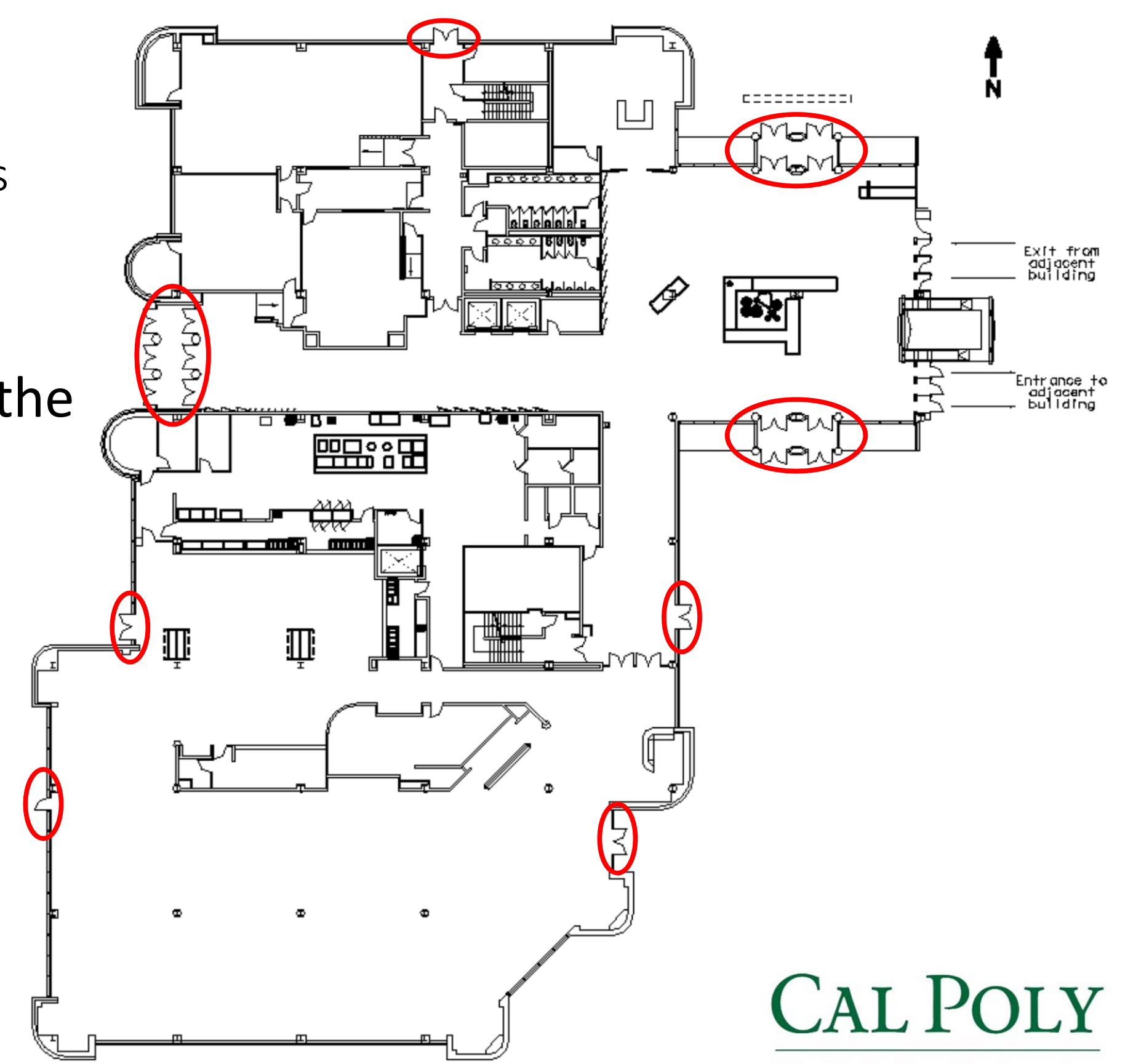

Fire Protection Engineering 


\section{Egress}

Second and Third Floor Exits
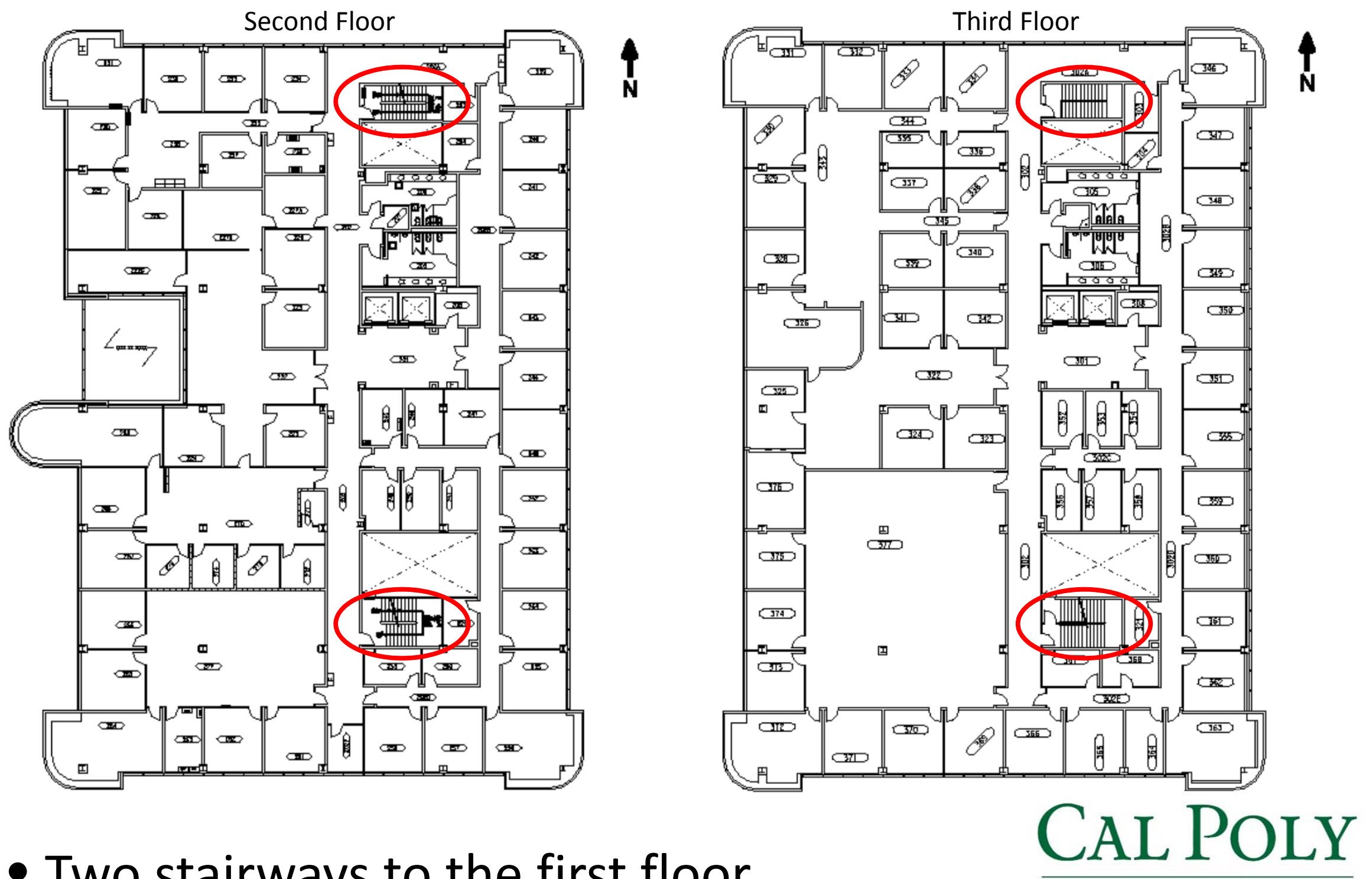

- Two stairways to the first floor 


\section{Detection and Notification}

FACP Location - First floor
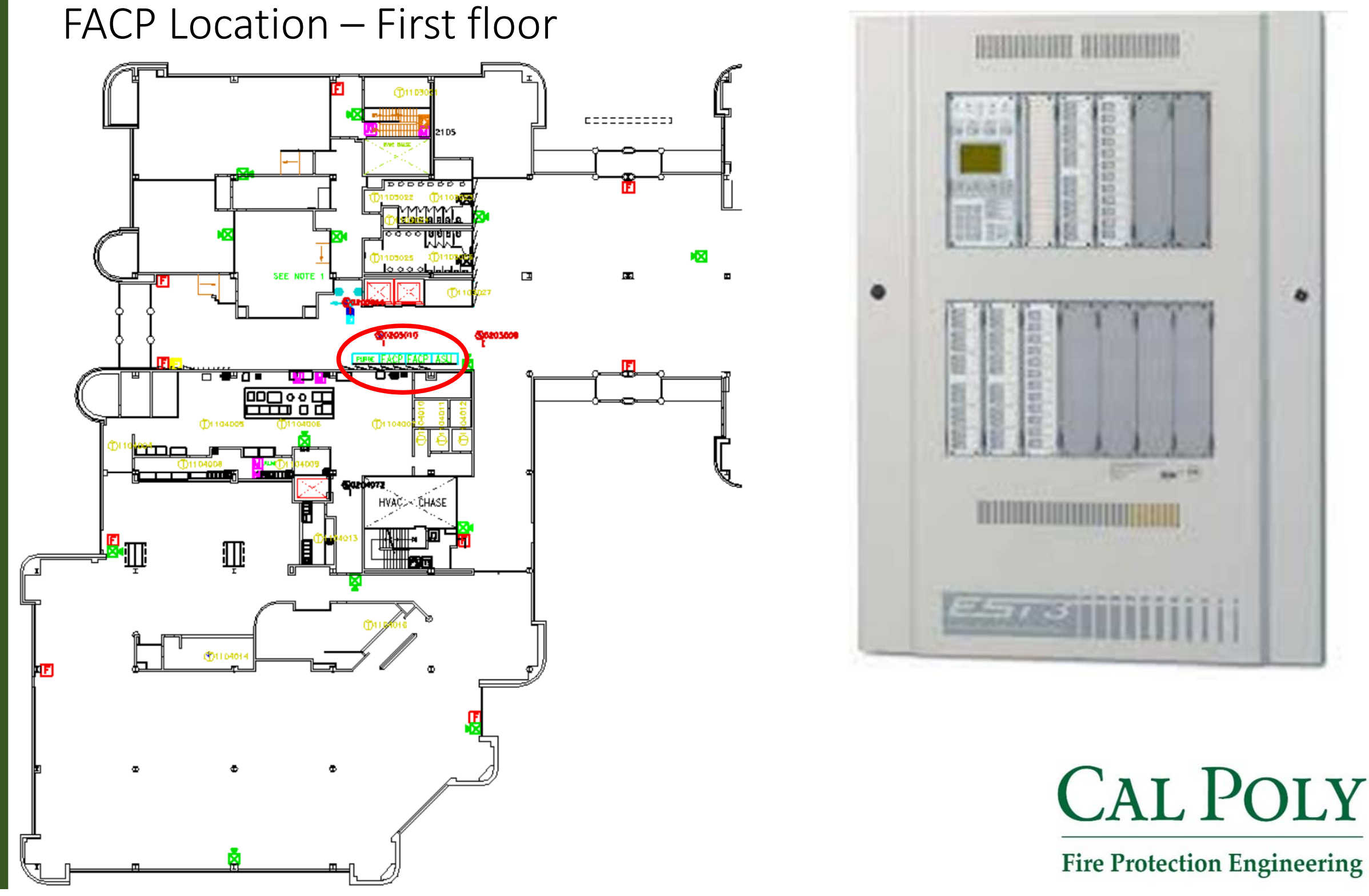

Fire Protection Engineering 


\section{Detection and Notification}

- Smoke Detectors in elevator shafts, lobbies, and control rooms

- Thermal detectors in kitchen areas

- Duct detectors on HVAC components

- Manual pull stations throughout
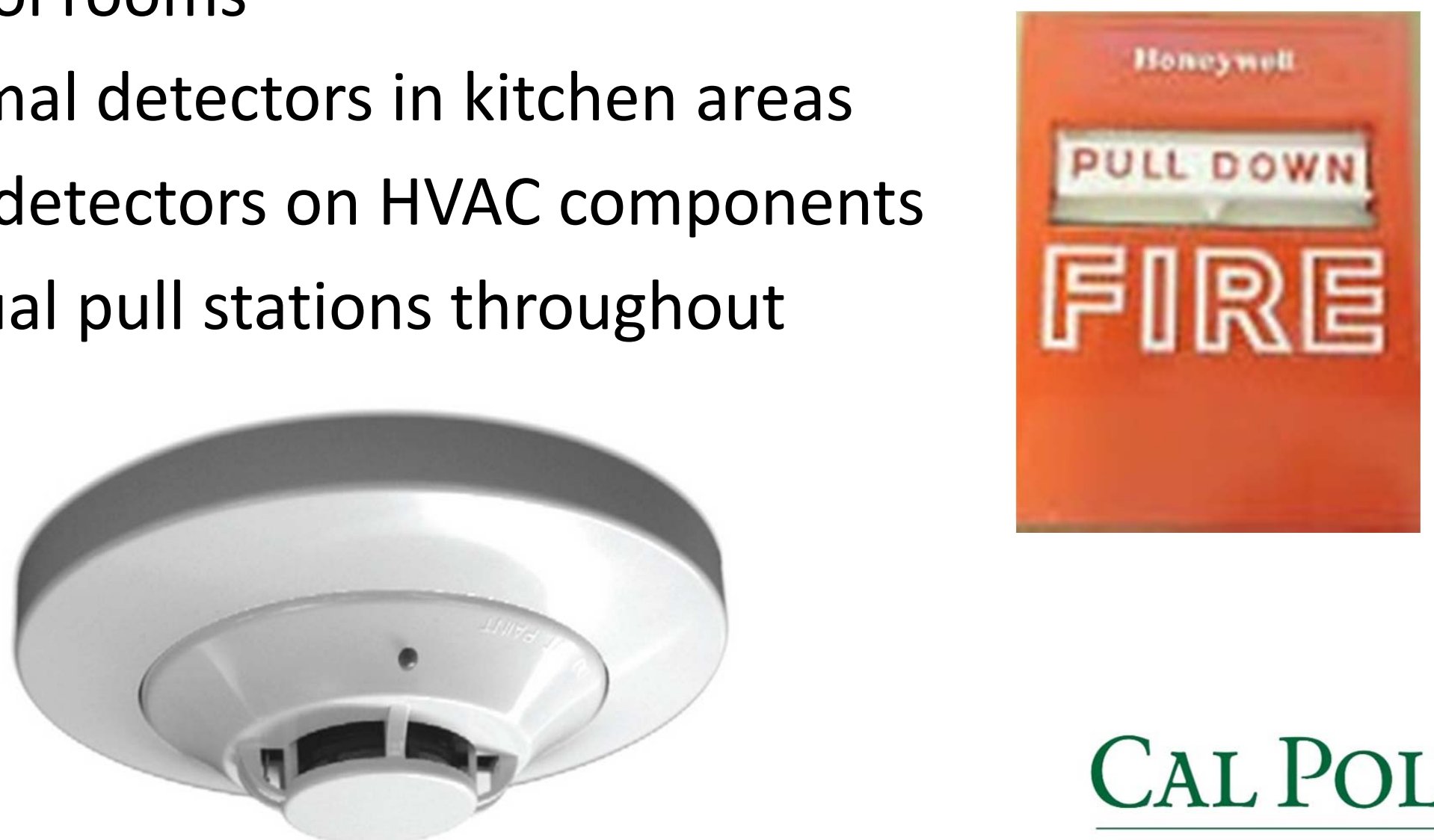


\section{Detection and Notification}

- Speaker and/or Strobe devices used throughout

- Water flow devices on sprinkler piping

- Tamper devices and monitor modules throughout
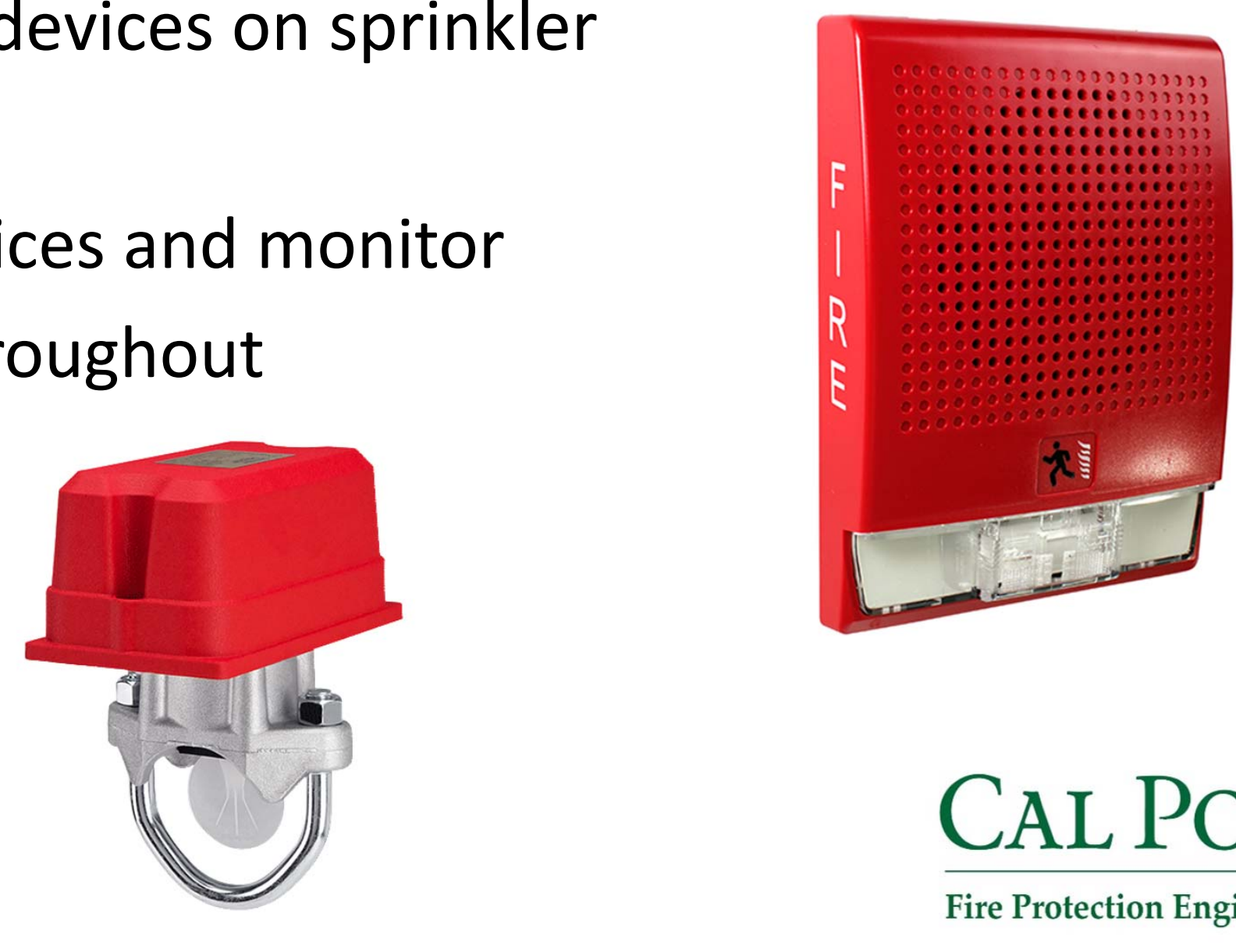


\section{Smoke Control}

- Duct detectors within HVAC components will shut down air handling units

- Fire department will break windows in the building if smoke purging is needed 


\section{Suppression}

Overview

- Automatic wet-pipe sprinkler system

- Double check valve at building entry point

- Victaulic fittings and black steel piping

- Standard temperature pendent and upright glass bulb sprinkler heads 


\section{Suppression}

Hazard Classification

- Ordinary Hazard Group 1

- Storage areas, kitchen, mechanical and electrical rooms

- Max sprinkler spacing - $130 \mathrm{sqft}$

- Sprinkler temp rating $-212^{\circ} \mathrm{F}$

- Light Hazard

- All other areas

- Max sprinkler spacing - 150 sqft

- Sprinkler temp rating $-165^{\circ} \mathrm{F}$ 


\section{Suppression}

Supply Information

- Main sprinkler supply test last conducted in 2013 at a hydrant located off the south side of the building

- Static Pressure $=95$ psi

- Residual Pressure $=87$ psi

- Flow = $1119 \mathrm{gpm}$ 


\section{Suppression}

Supply and FD Connection

- Supply main entry point on south end of basement

- Dry standpipes for FD connections enter on both north and south ends of the basement

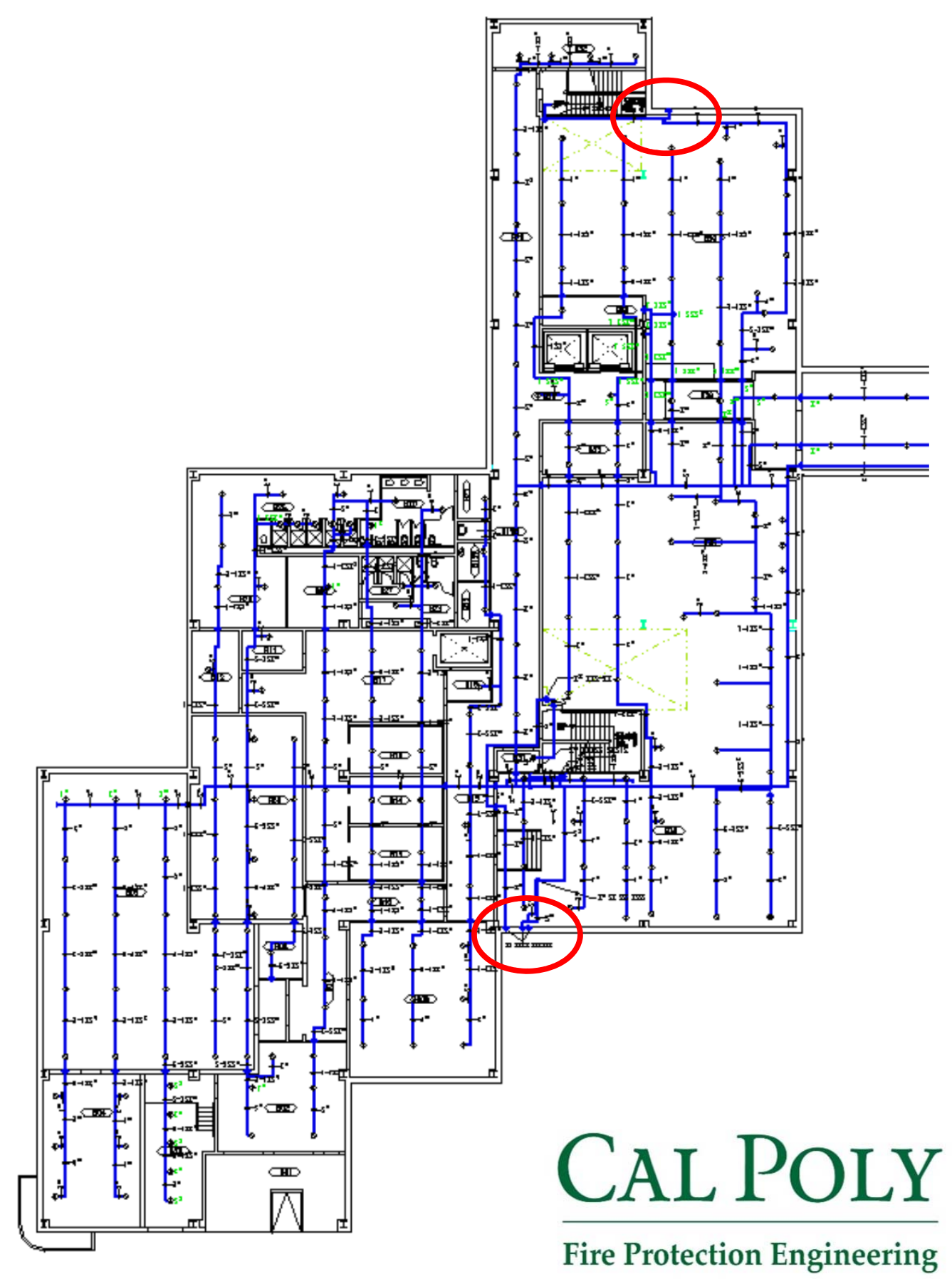




\section{Tenability Criteria}

- Objective

- Maintain tenable conditions during egress times

- Criteria

- CO concentration: 1100 ppm for CO

- Visibility: 6 meters

- Temperature: $60^{\circ} \mathrm{C}$ 


\section{Fire Scenario 1}

Office Workstation

- Cubicle furniture on the third floor

- Source: Space heater

- Area: $2887 \mathrm{ft}^{2}$

- 9' false ceiling, $15^{\prime}$ to deck

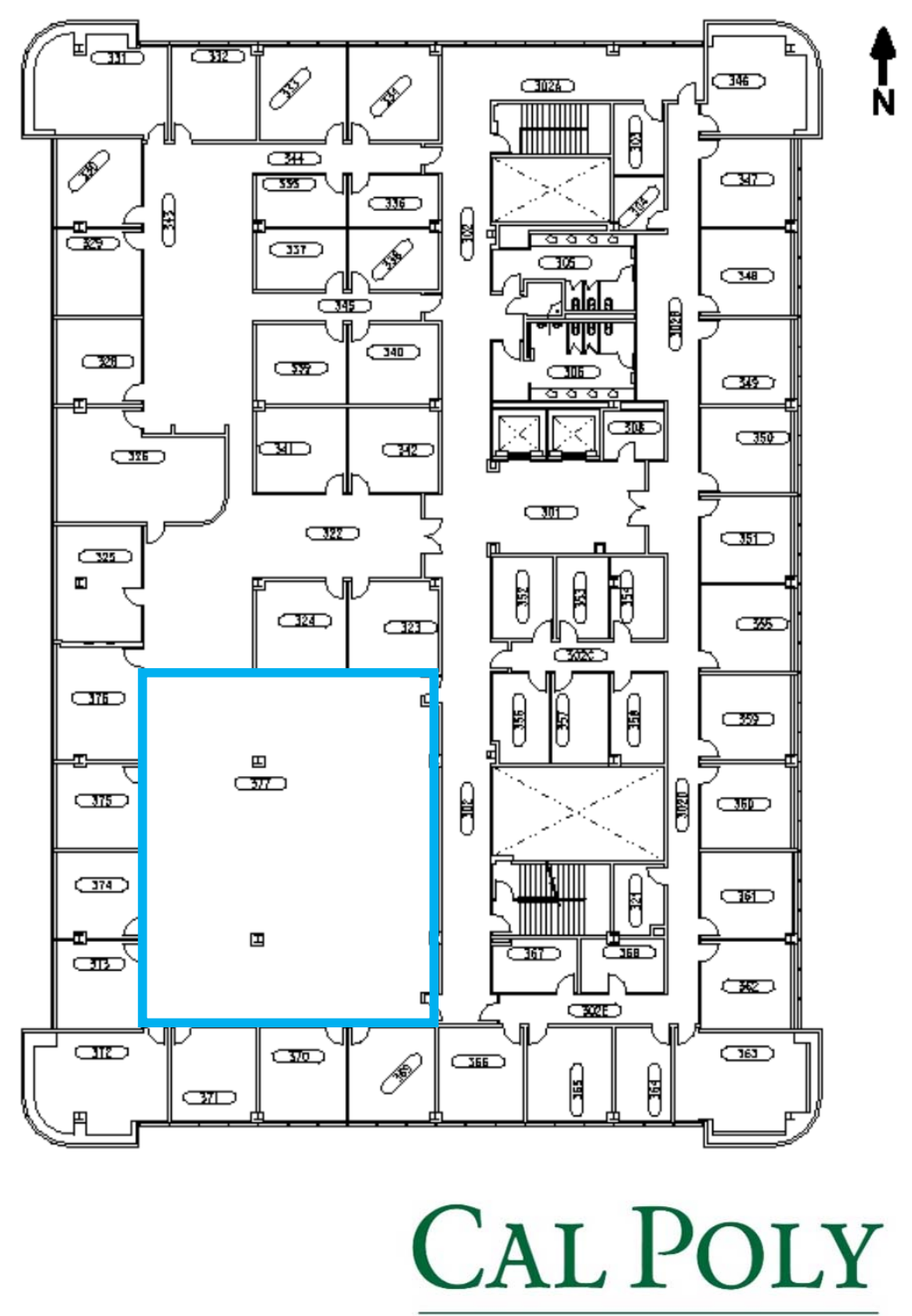

Fire Protection Engineering 


\section{Fire Scenario 1}

Office Workstation

- Assume adjoining office doors are closed and both entrance doors are closed

- Assume supply air into the space is zero due to shut down of Air Handling Unit

- No detectors in the area

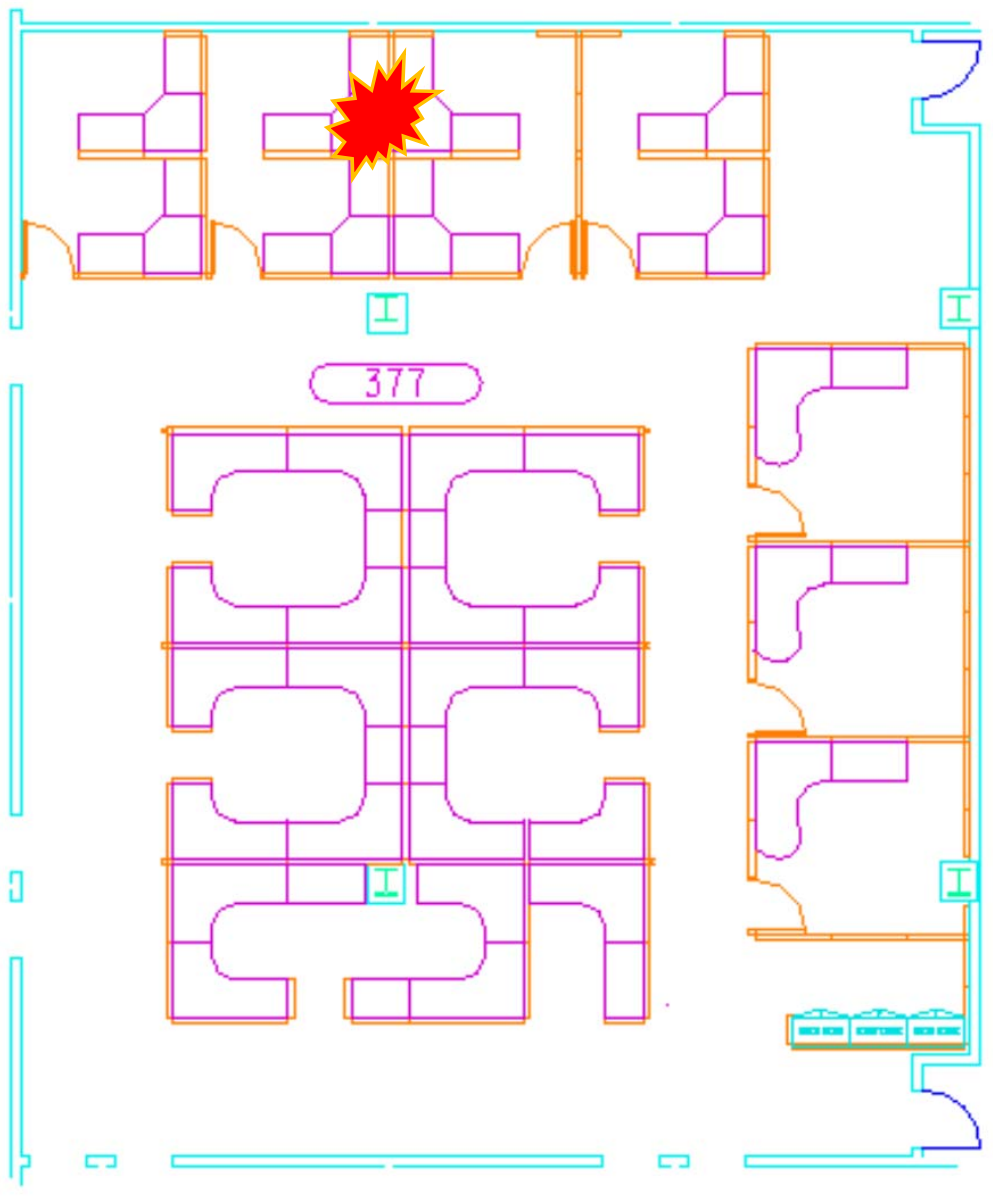




\section{Fire Scenario 1}

Office Workstation

- SFPE Handbook Data for HRR

- $2000 \mathrm{~kW}$ peak HRR at approximately 500 seconds

- Sprinkler activation at 415 seconds, HRR held constant at this time

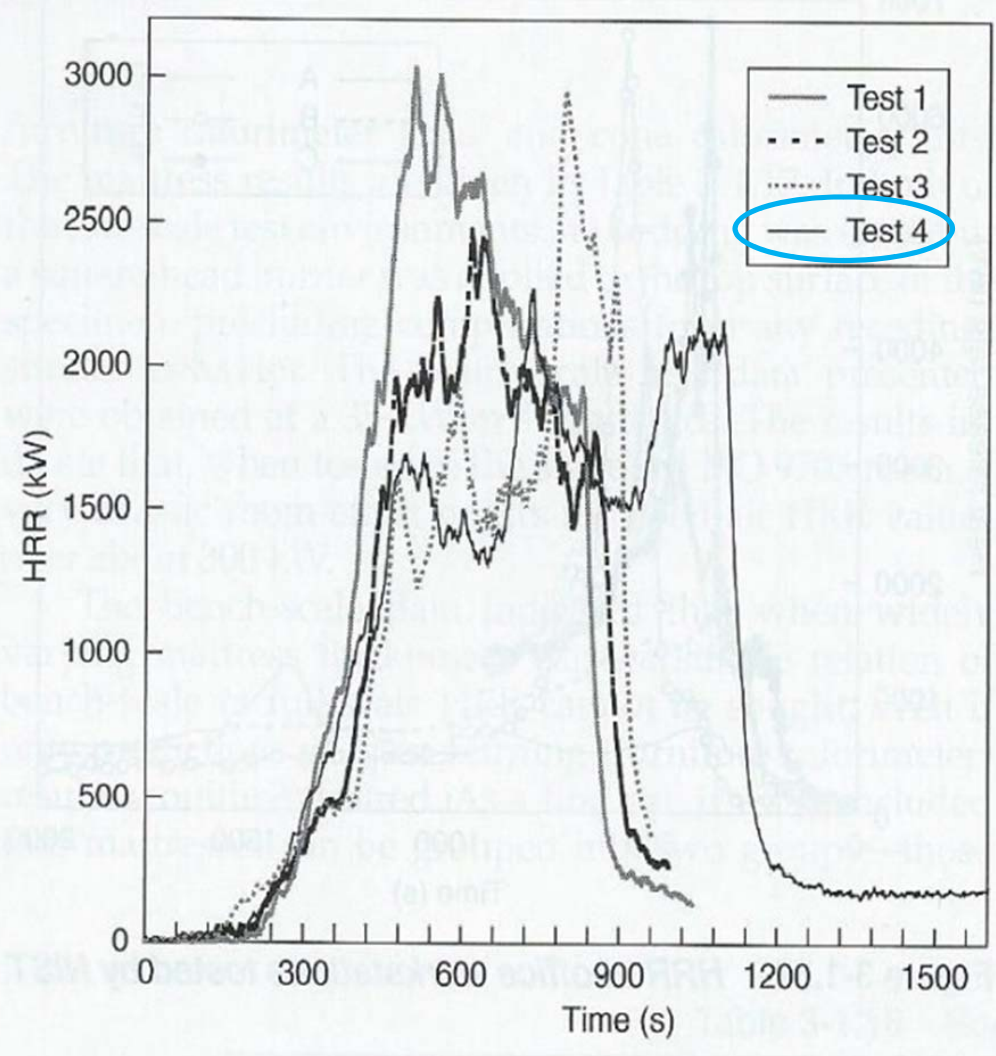

Figure 3-1.61. HRR of four unit workstations tested at NRIFD. 


\section{Fire Scenario 1}

RSET

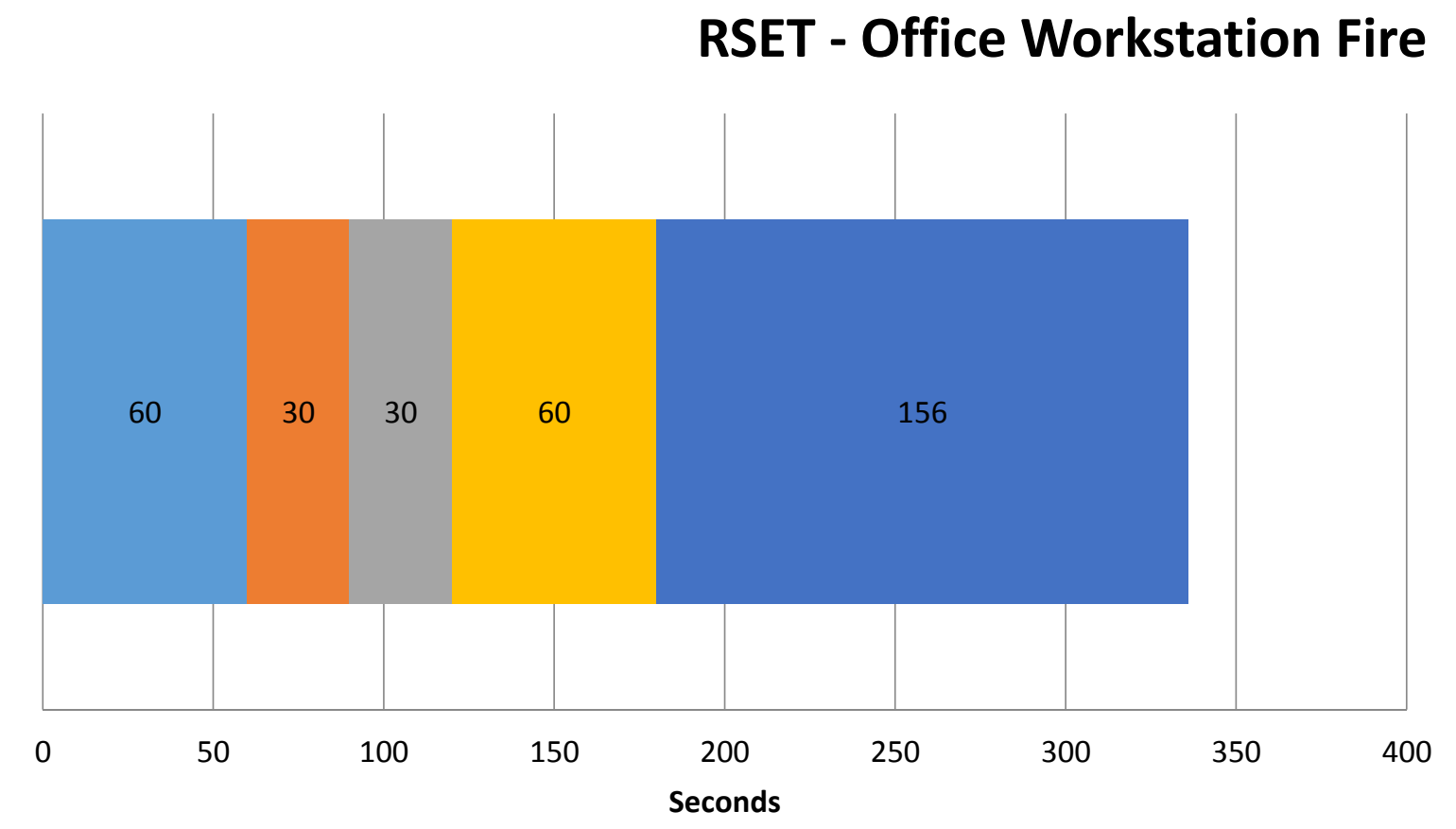

Ignition to Detection

Detection Time to Initiation/Notification

notification to Egress Decision

Egress Decision to Movement

- Initial Movement to Complete Evacuation

- Total RSET = 366 seconds 


\section{Fire Scenario 1}

ASET - Carbon Monoxide (1100 ppm)

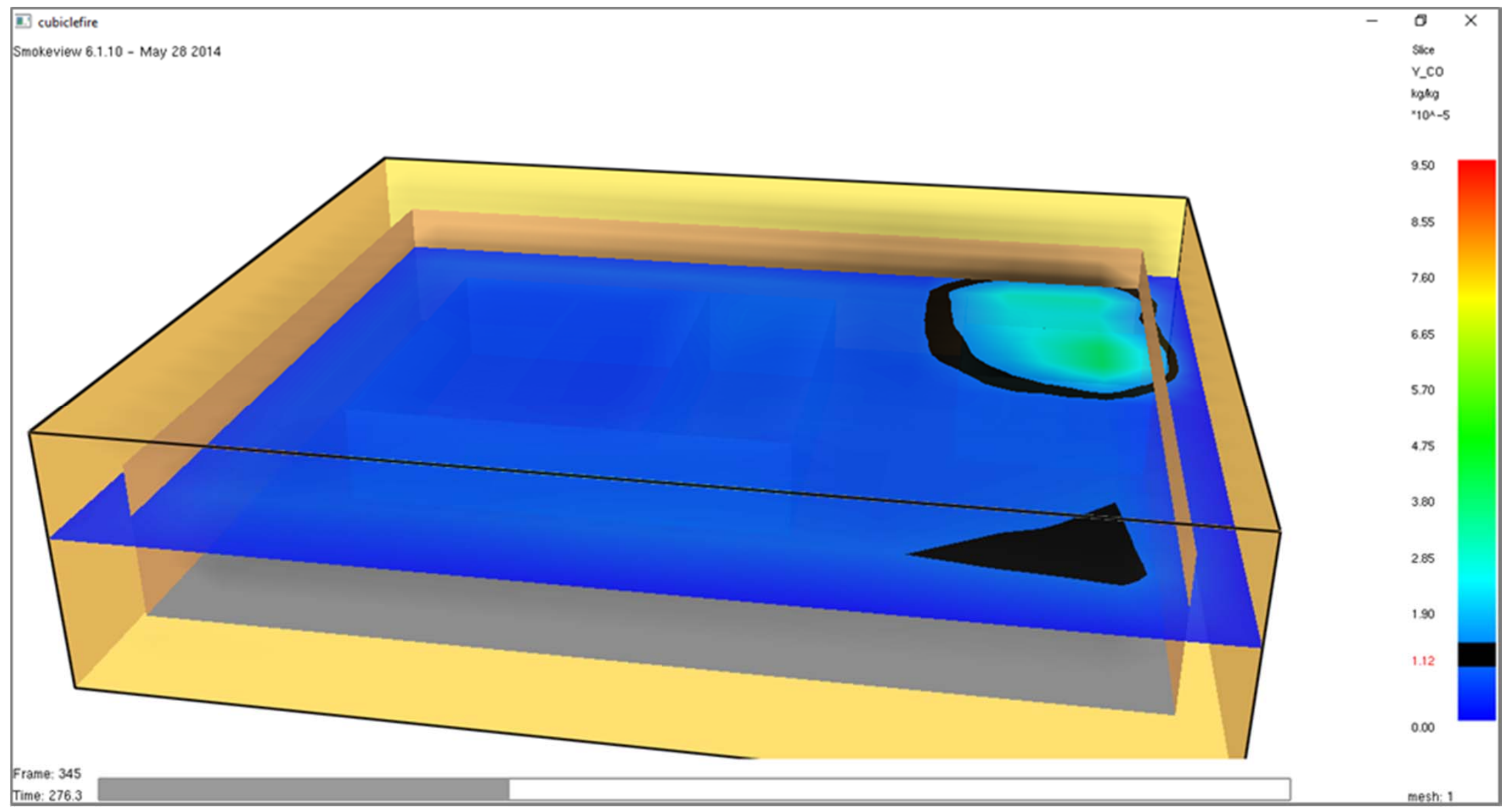

- CO concentration increases at $276 \mathrm{~s}$ 


\section{Fire Scenario 1}

ASET - Visibility (4 meters)

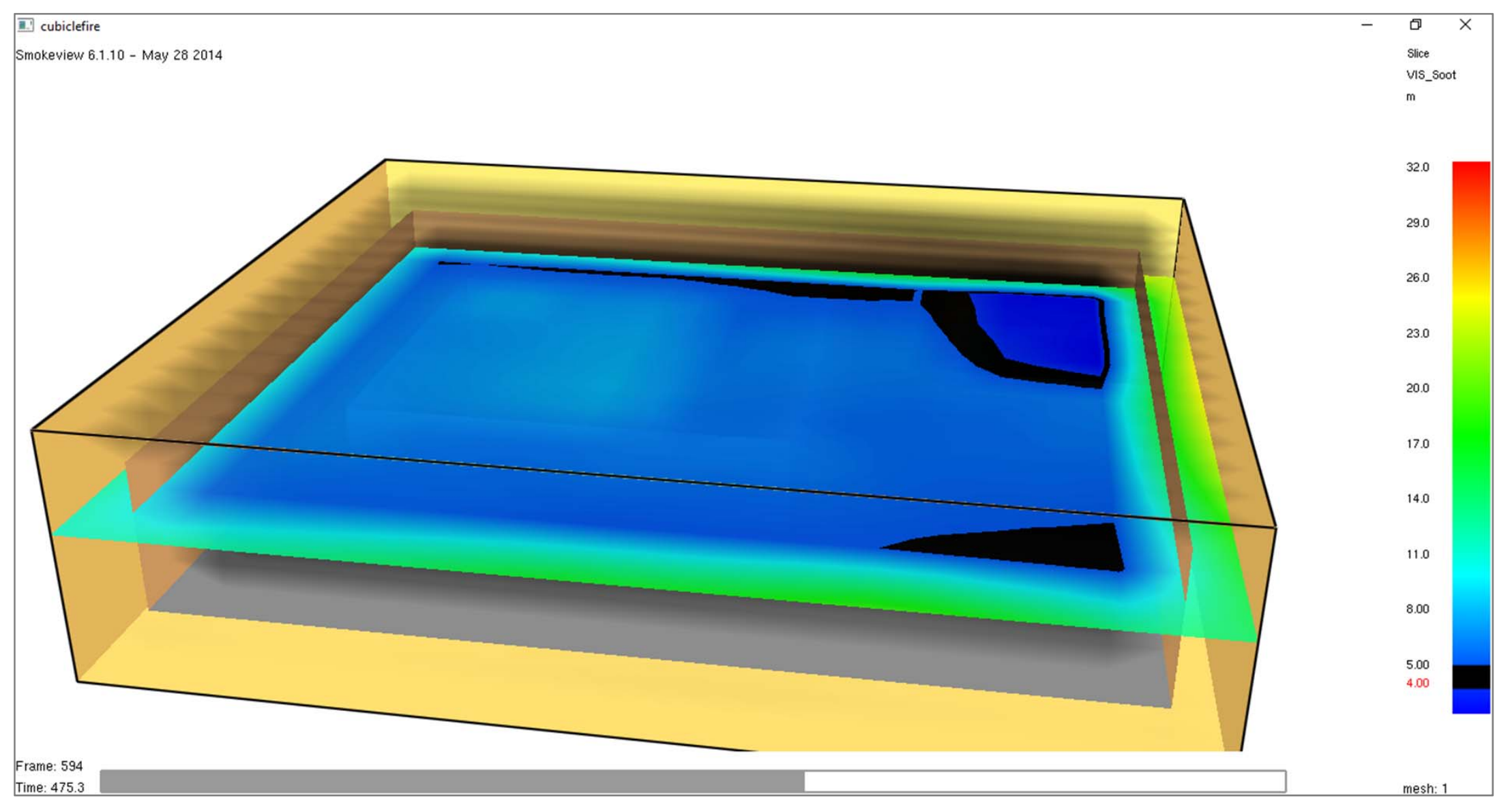

- Visibility drops below 4 meters at $475 \mathrm{~s}$ 


\section{Fire Scenario 1}

ASET - Temperature $\left(60^{\circ} \mathrm{C}\right)$

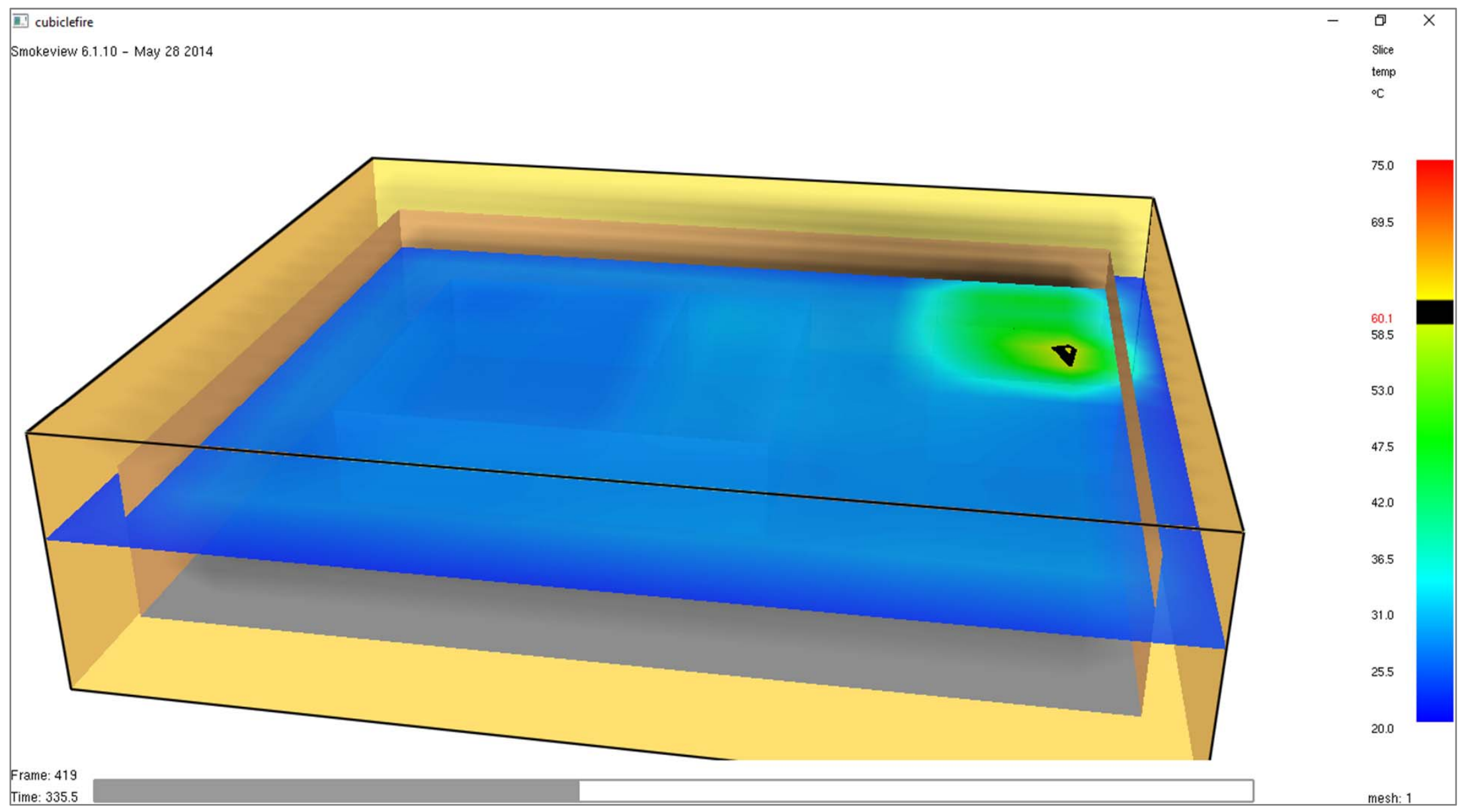

- Temperature at $60^{\circ} \mathrm{C}$ at $335 \mathrm{~s}$ 


\section{Fire Scenario 1}

ASET vs RSET

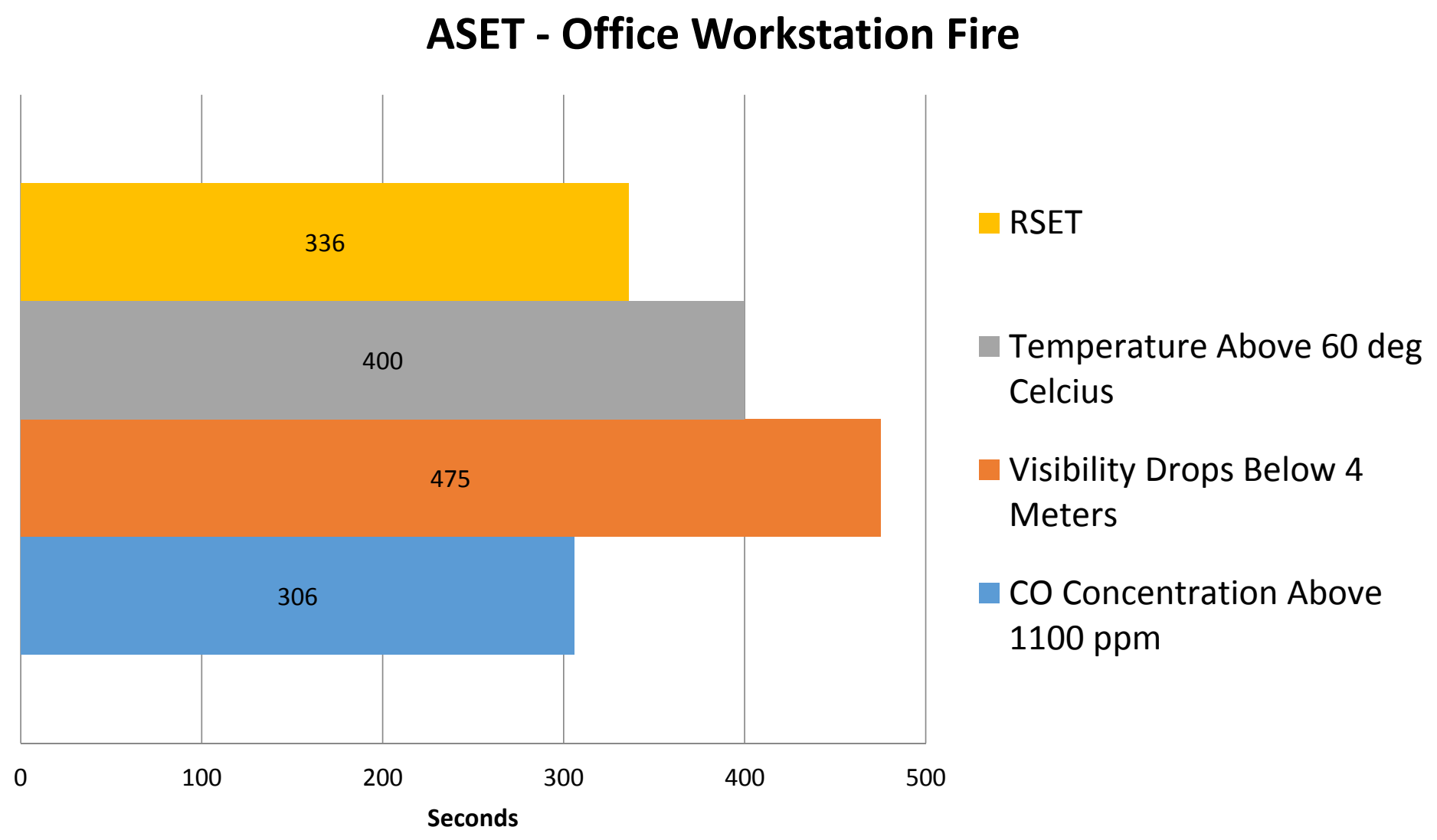

- $\mathrm{CO}$ is the limiting factor 


\section{Fire Scenario 1}

Summary/Recommendations

- $\mathrm{CO}$ is the limiting factor

- Recommendation:

- Install smoke detectors in the space to try to reduce detection, alarm, and notification times and therefore reducing evacuation time

- Use the HVAC system to purge smoke and toxic gases in the event of a fire 


\section{Fire Scenario 2}

Convenience Store

- Display/storage unit in the convenience store

- Source: Electrical

- Store Area: $945 \mathrm{ft}^{2}$

- Lobby Area: $8000 \mathrm{ft}^{2}$

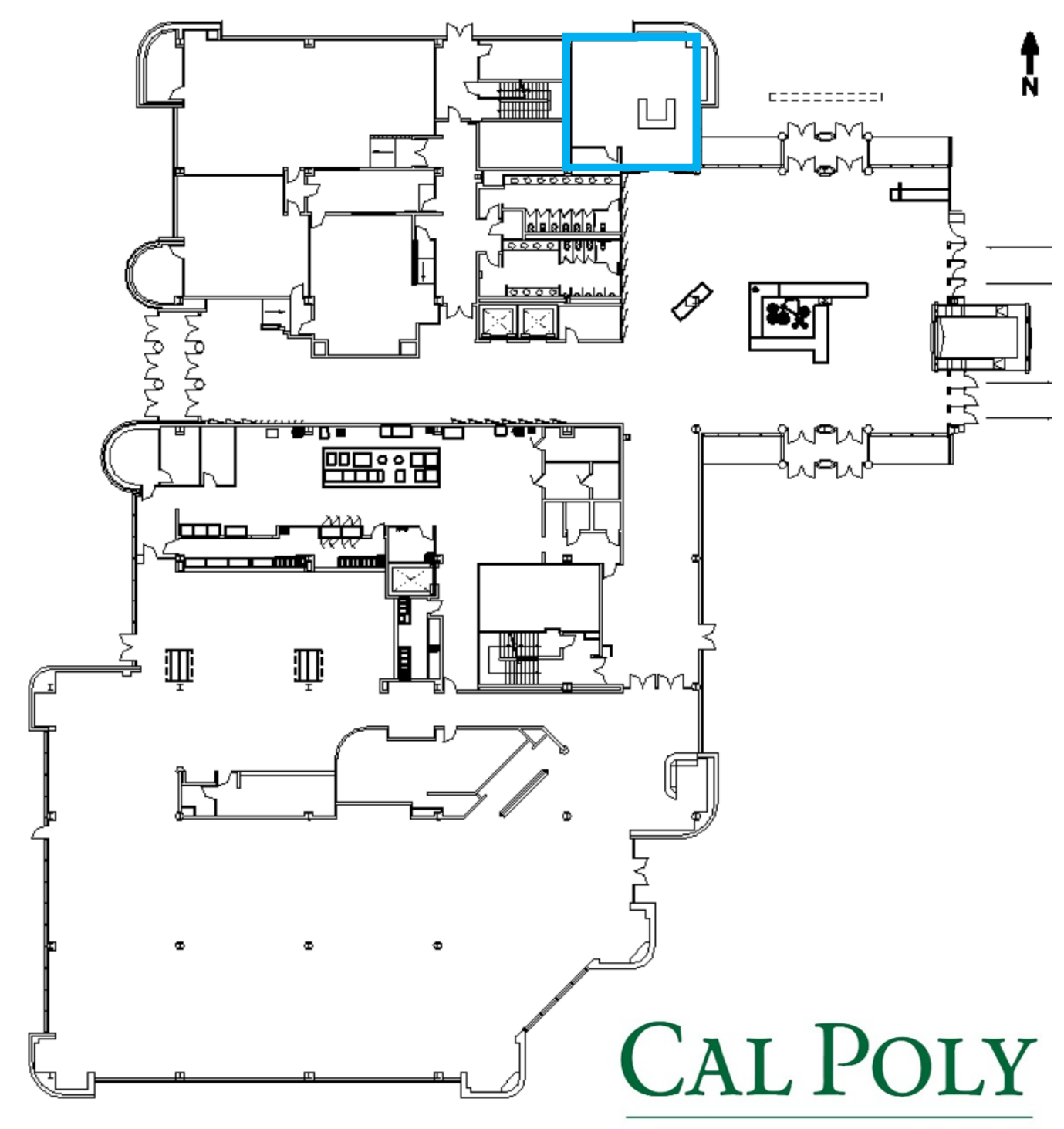




\section{Fire Scenario 2}

Convenience Store

- No detectors

- Fire occurs during normal business hours

- Occupants do not attempt to fight the fire

- 3 areas looked at

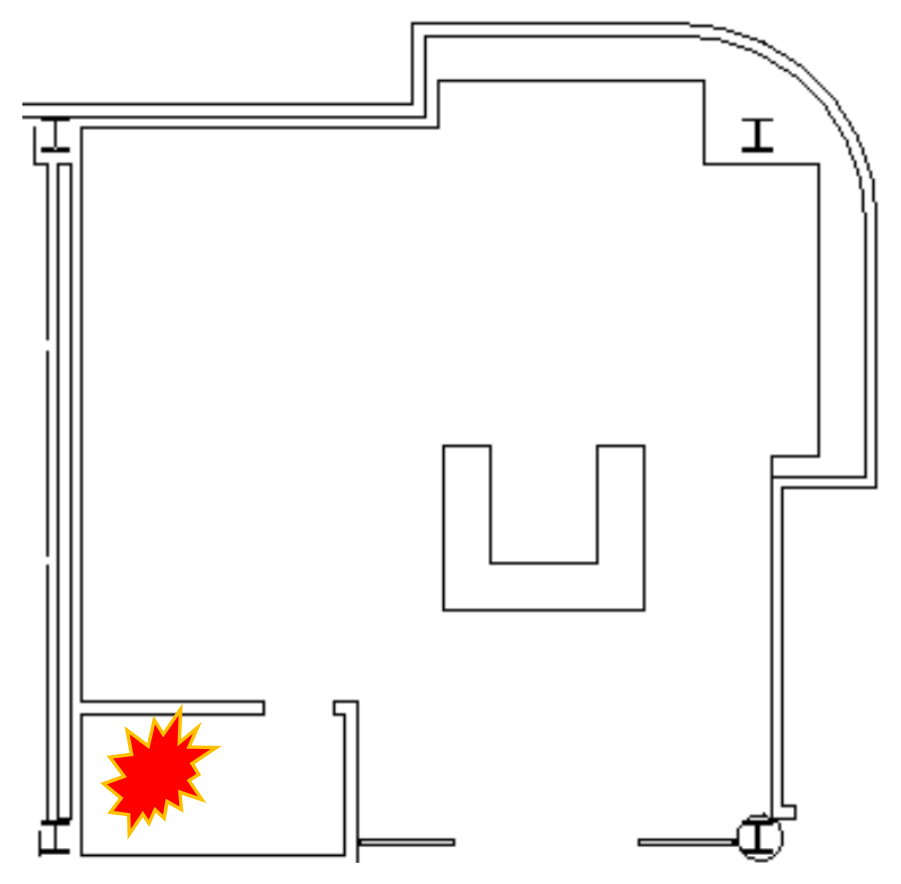

- Small office/storage room

- Store

- Lobby 


\section{Fire Scenario 2}

Convenience Store

- $6 \mathrm{MW}$ peak HRR at approximately 300 seconds

- SFPE Handbook Data

- Fire ramp information was altered to a maximum of $2000 \mathrm{~kW}$ due to the size of the area where the fire begins

- Sprinkler activation at 50 seconds

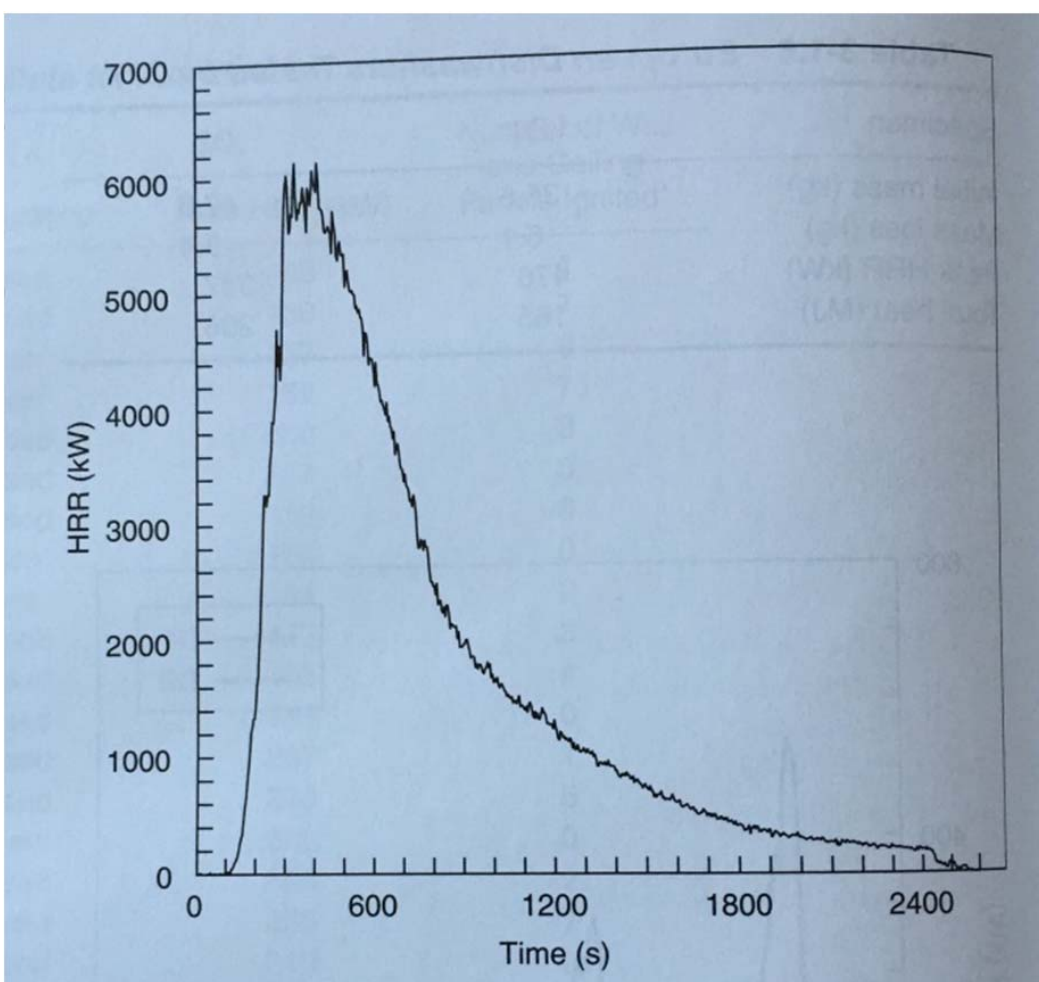

Figure 3-1.41. HRR of potato chips and cheese nibbles set up in a shop display unit. 


\section{Fire Scenario 2}

RSET

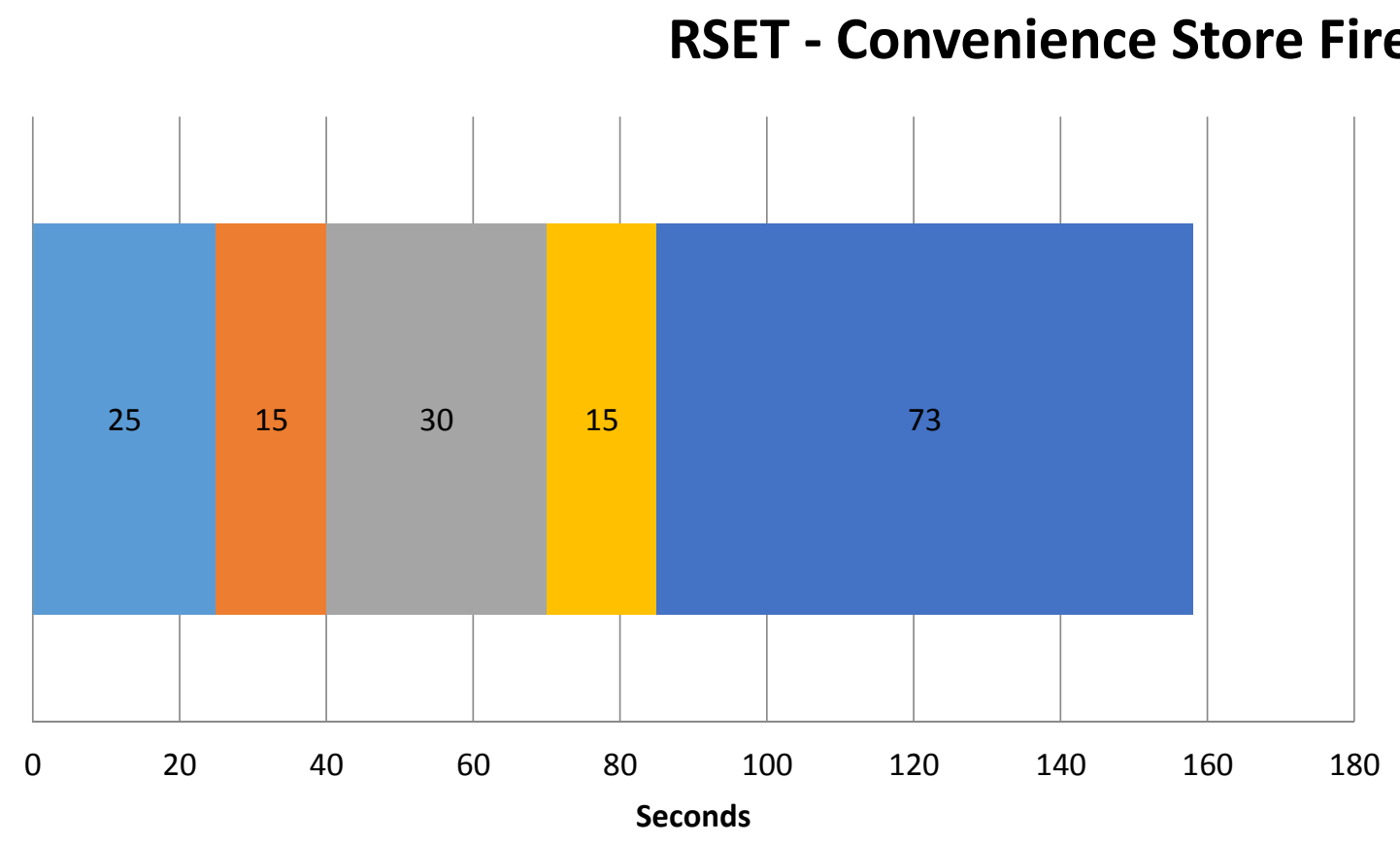

Ignition to Detection

Detection Time to Initiation/Notification

Notification to Egress Decision

Egress Decision to Movement

- Initial Movement to Complete Evacuation

- Overall First Floor RSET = 158 seconds 


\section{Fire Scenario 2}

ASET - Carbon Monoxide (1100ppm)

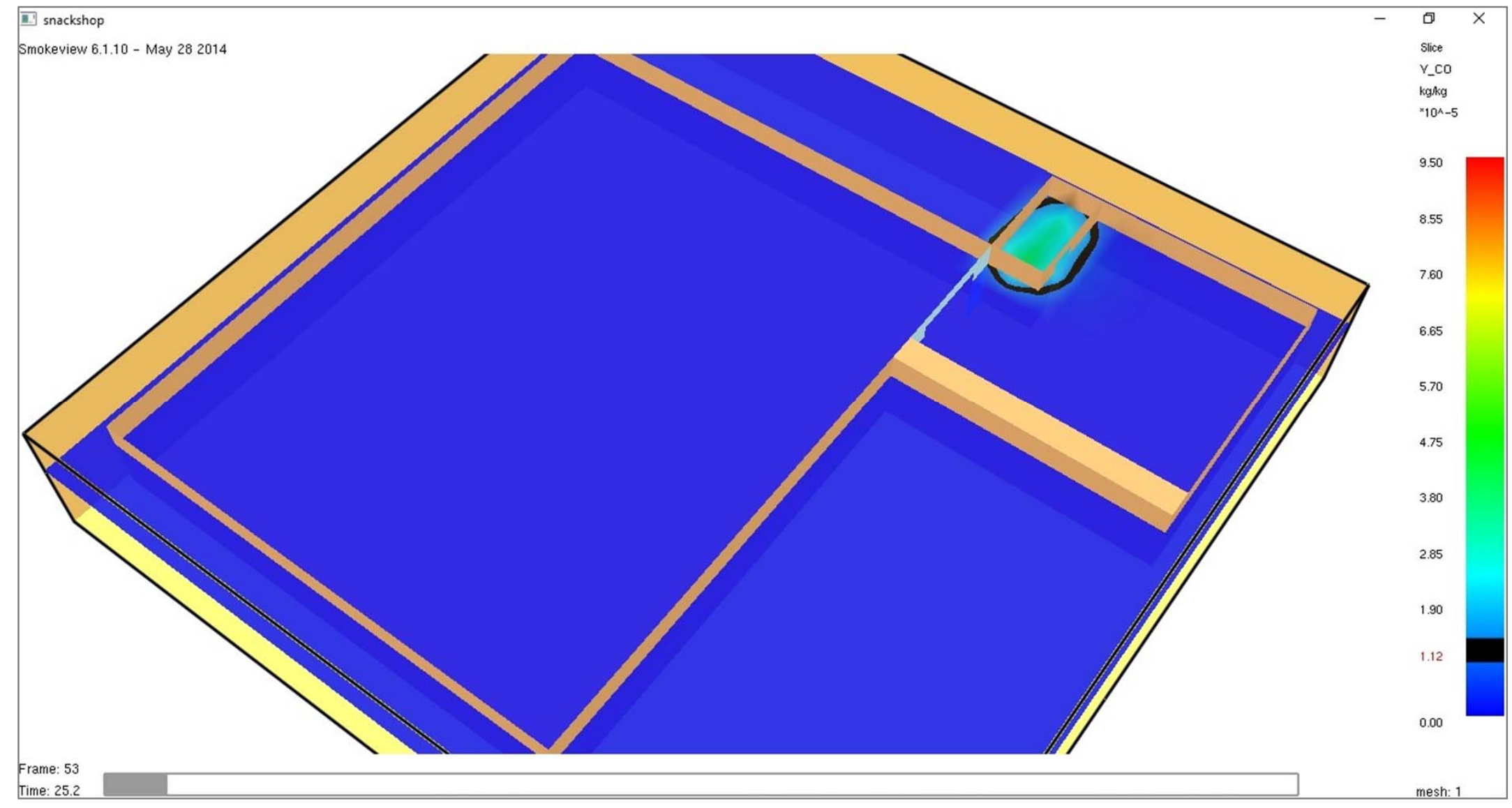

- CO level in storage room at 25 seconds 


\section{Fire Scenario 2}

ASET - Carbon Monoxide (1100ppm)

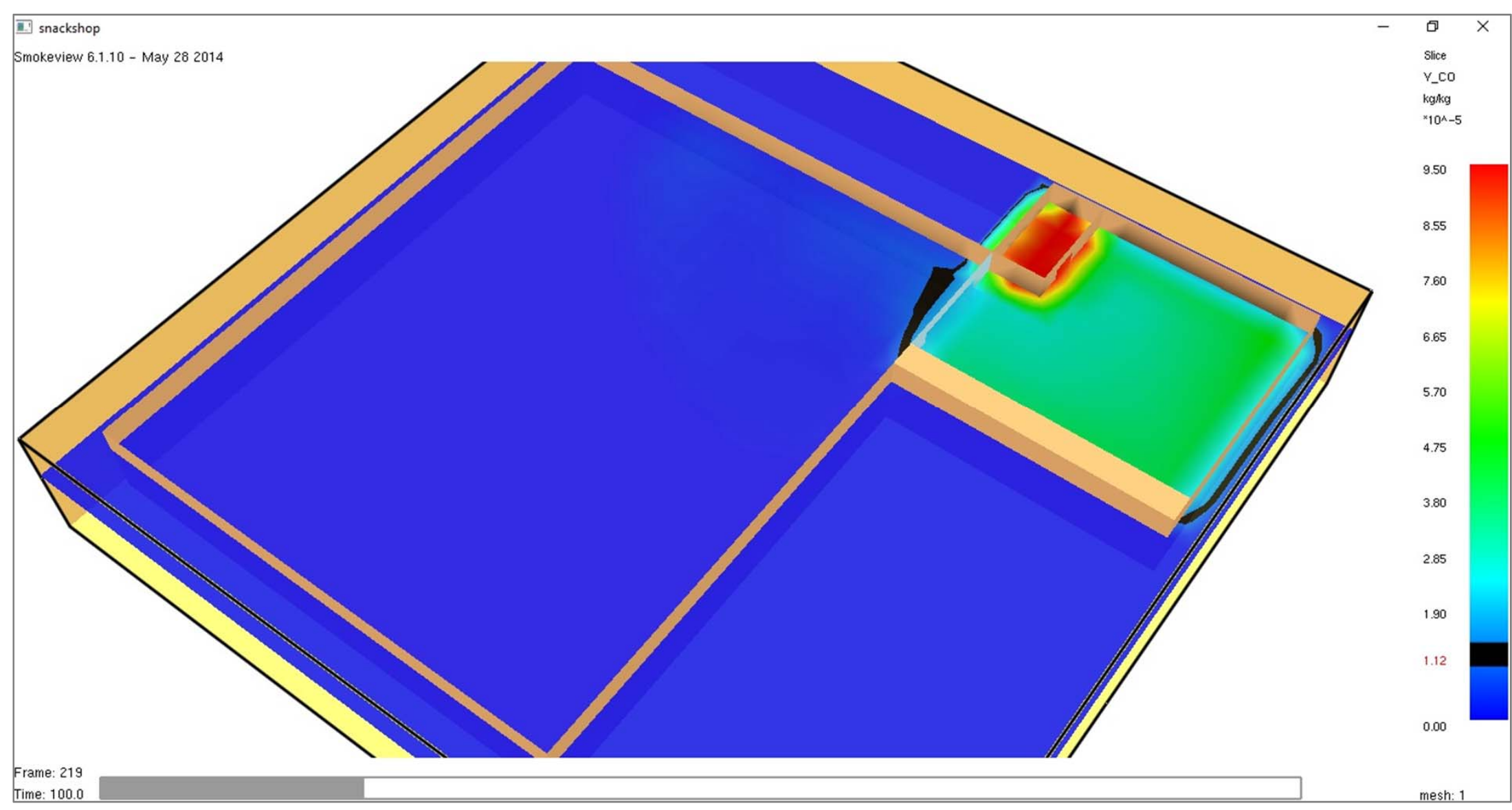

- CO level at 100 seconds 


\section{Fire Scenario 2}

ASET - Carbon Monoxide (1100ppm)

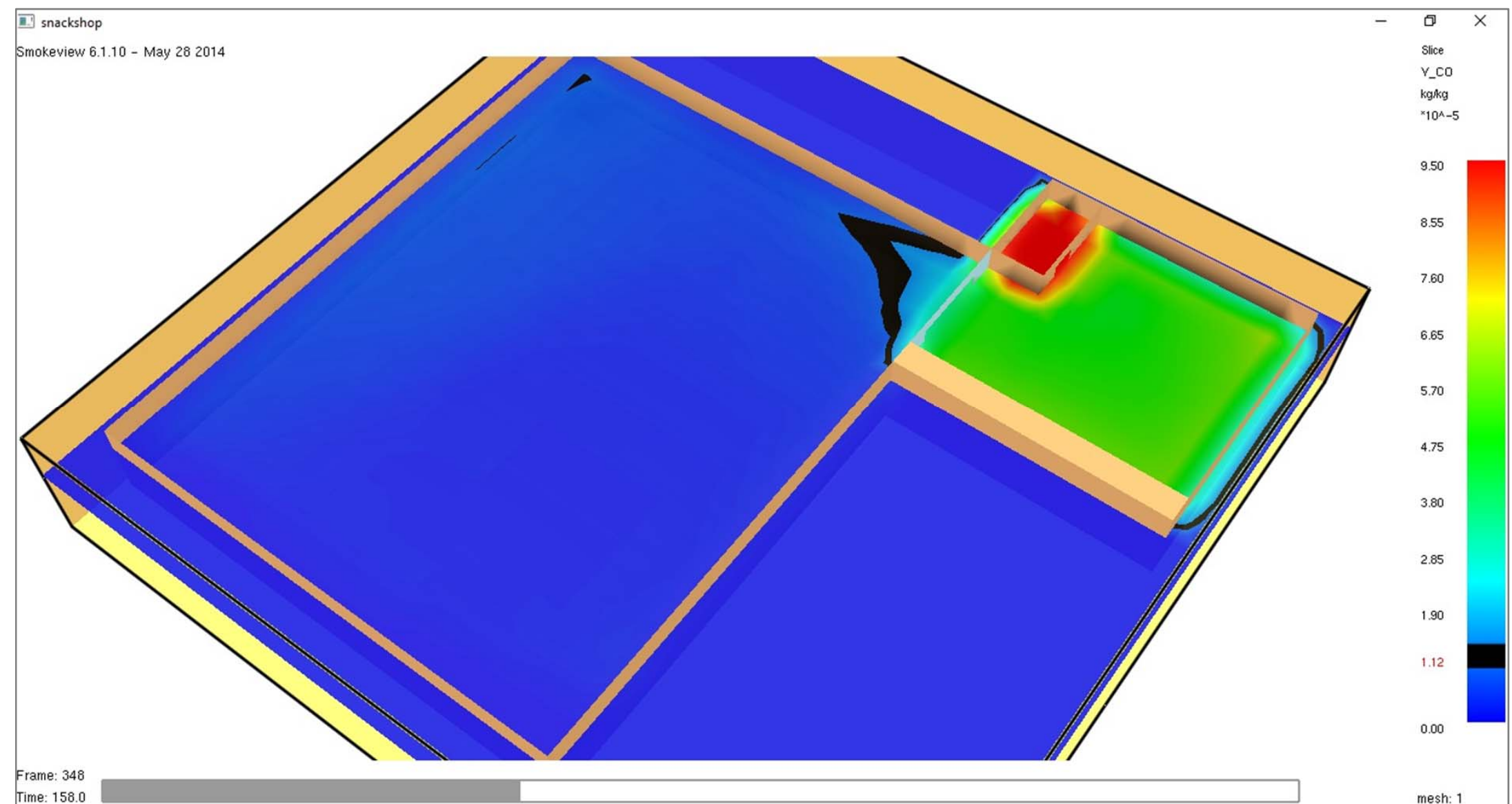

- CO level at RSET (158 seconds) 


\section{Fire Scenario 2}

ASET - Visibility (6 meters)

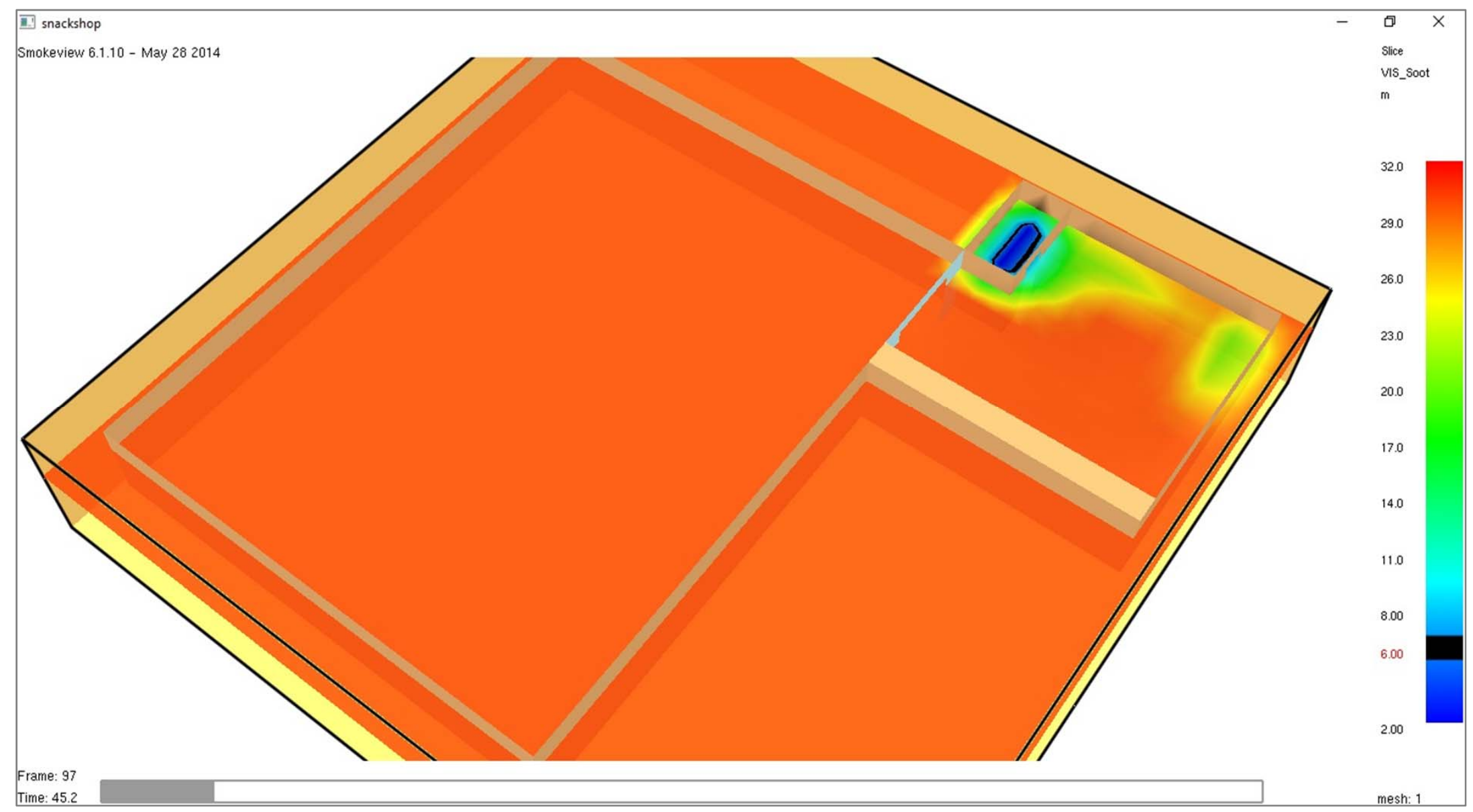

- Visibility at 45 seconds 
Fire Scenario 2

ASET - Visibility (6 meters)

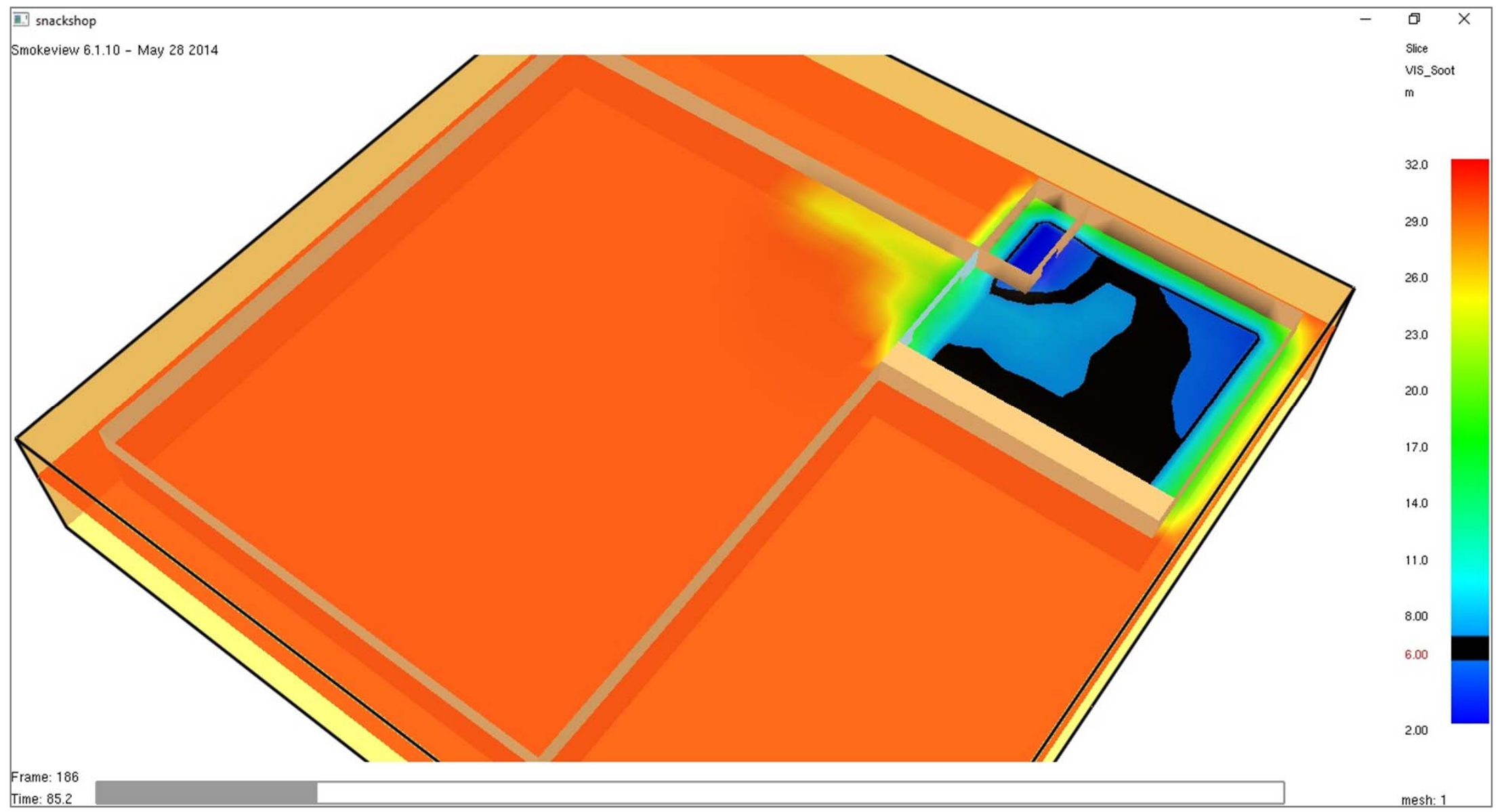

- Visibility at 85 seconds 


\section{Fire Scenario 2}

ASET - Visibility (6 meters)

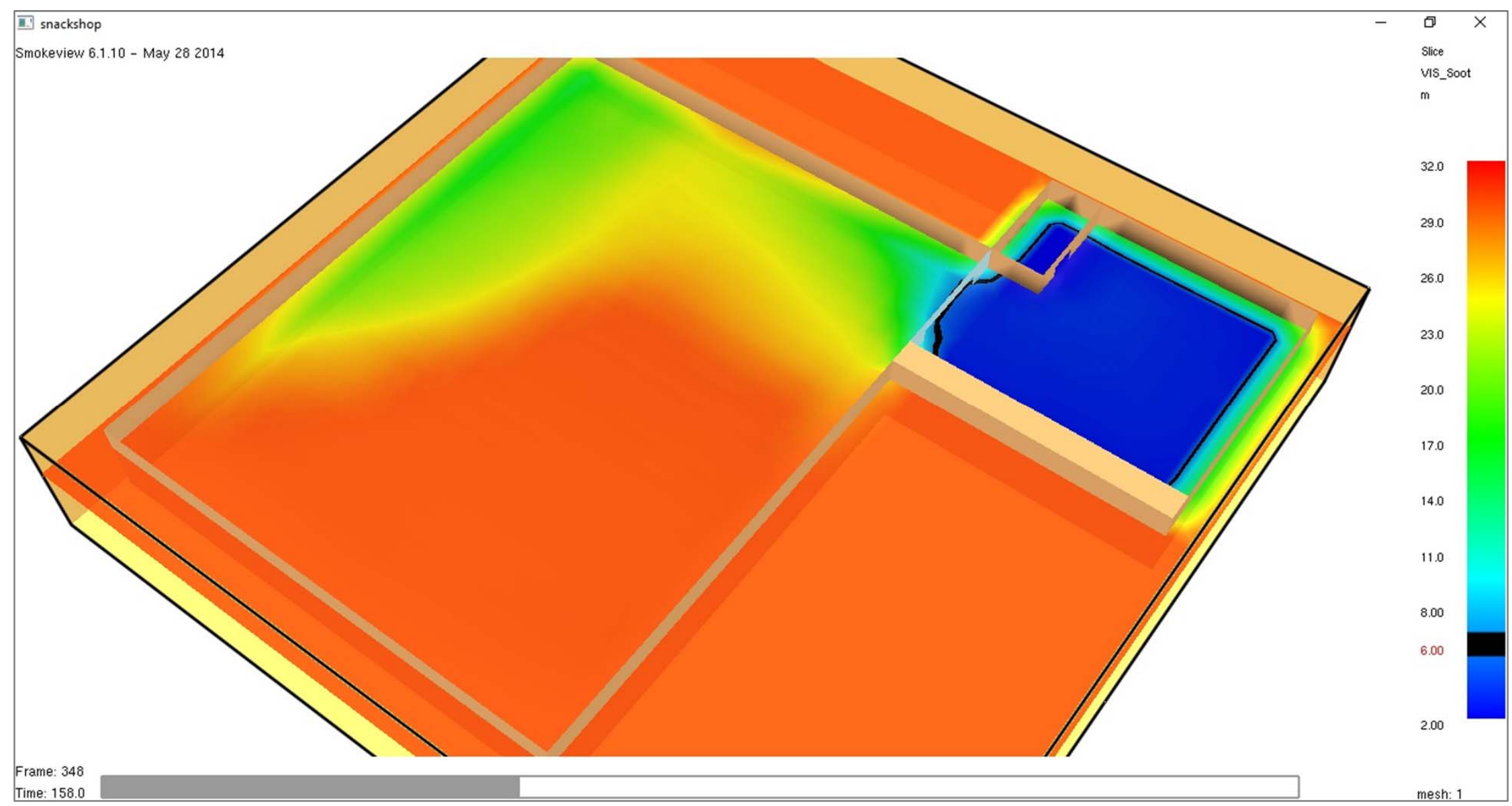

- Visibility at RSET (158 seconds) 
Fire Scenario 2

ASET - Temperature $\left(60^{\circ} \mathrm{C}\right)$

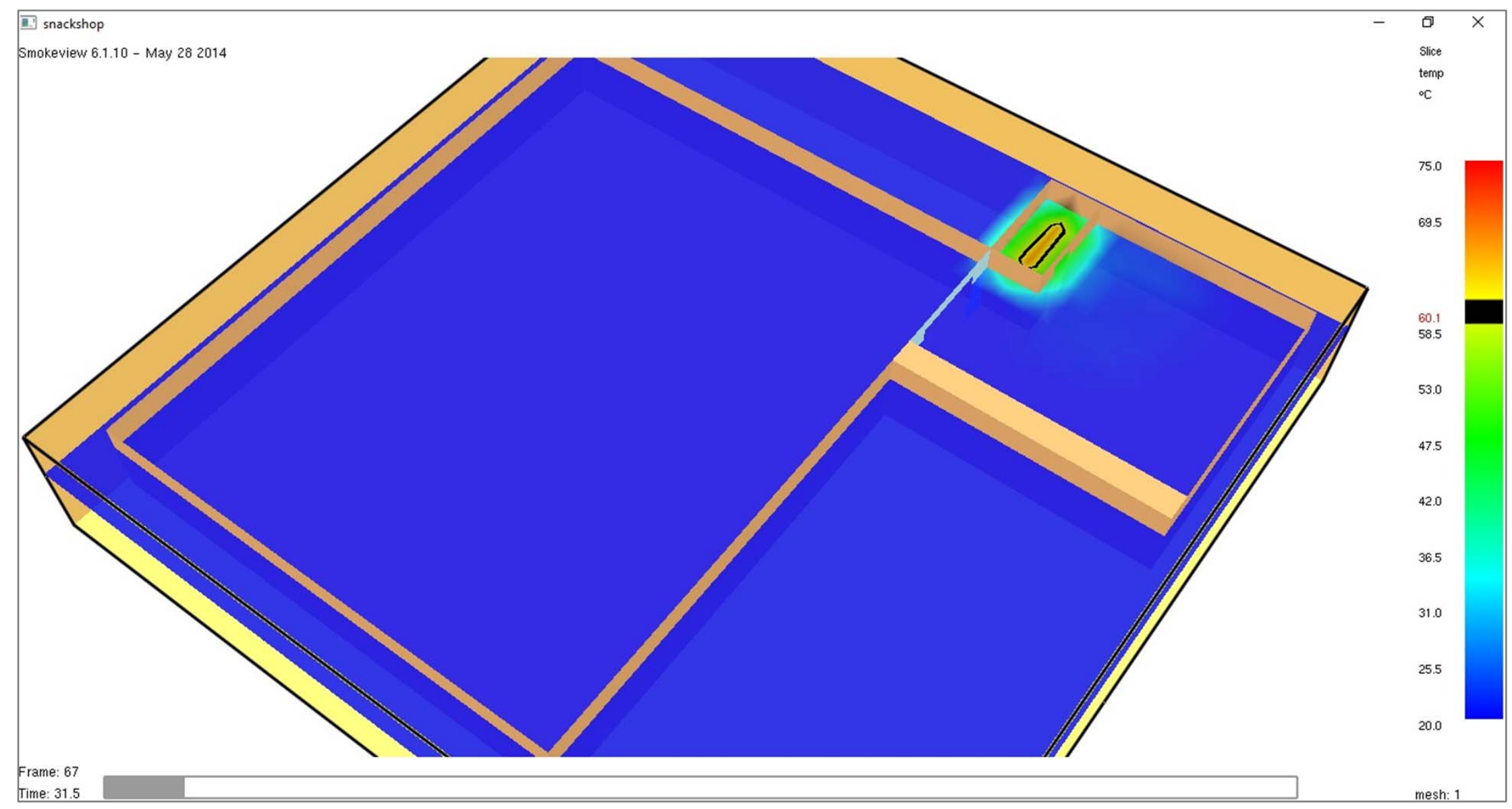

- Temperature at 31 seconds 
Fire Scenario 2

ASET - Temperature $\left(60^{\circ} \mathrm{C}\right)$

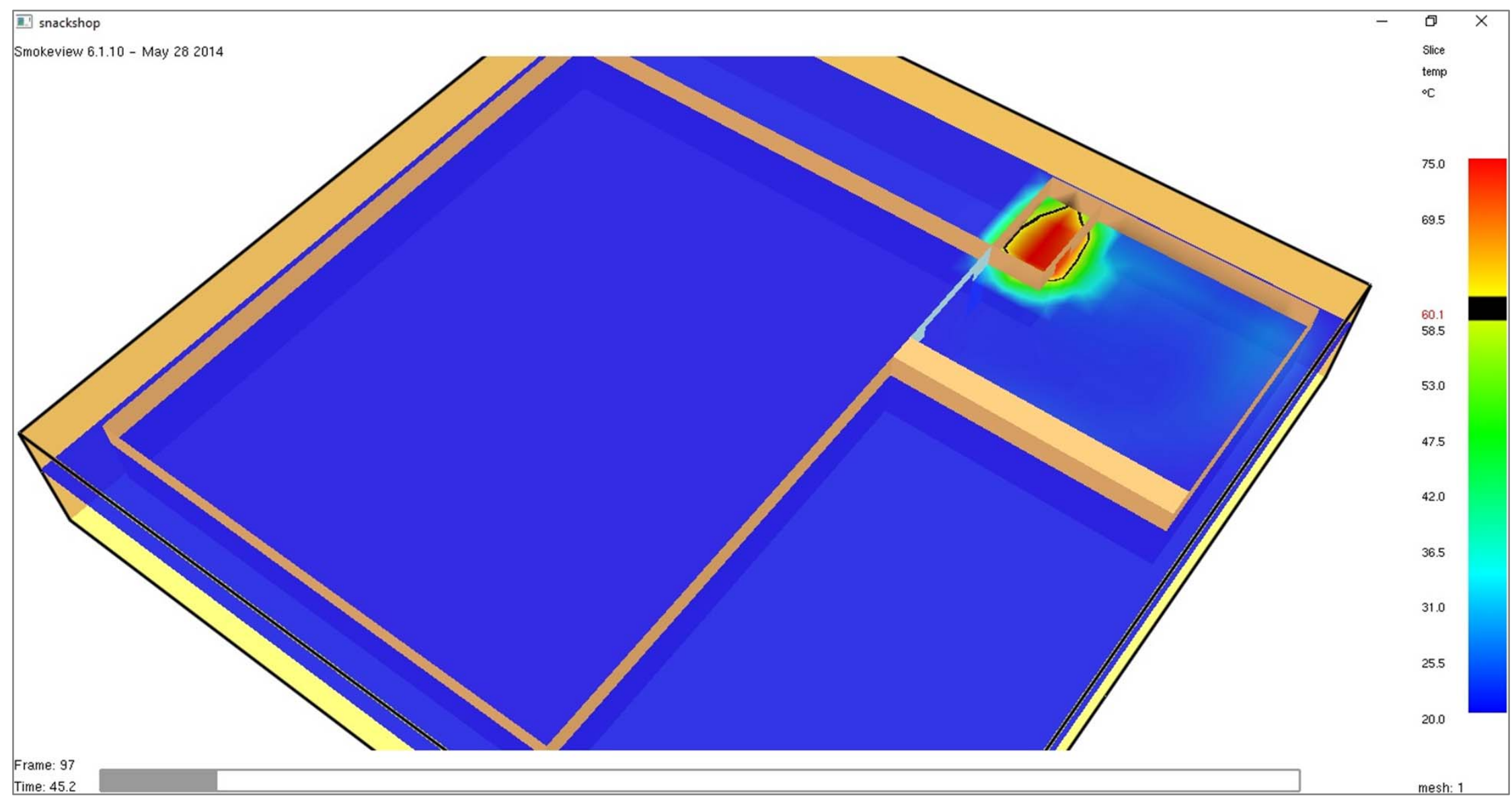

- Temperature at 45 seconds 


\section{Fire Scenario 2}

ASET - Temperature $\left(60^{\circ} \mathrm{C}\right)$

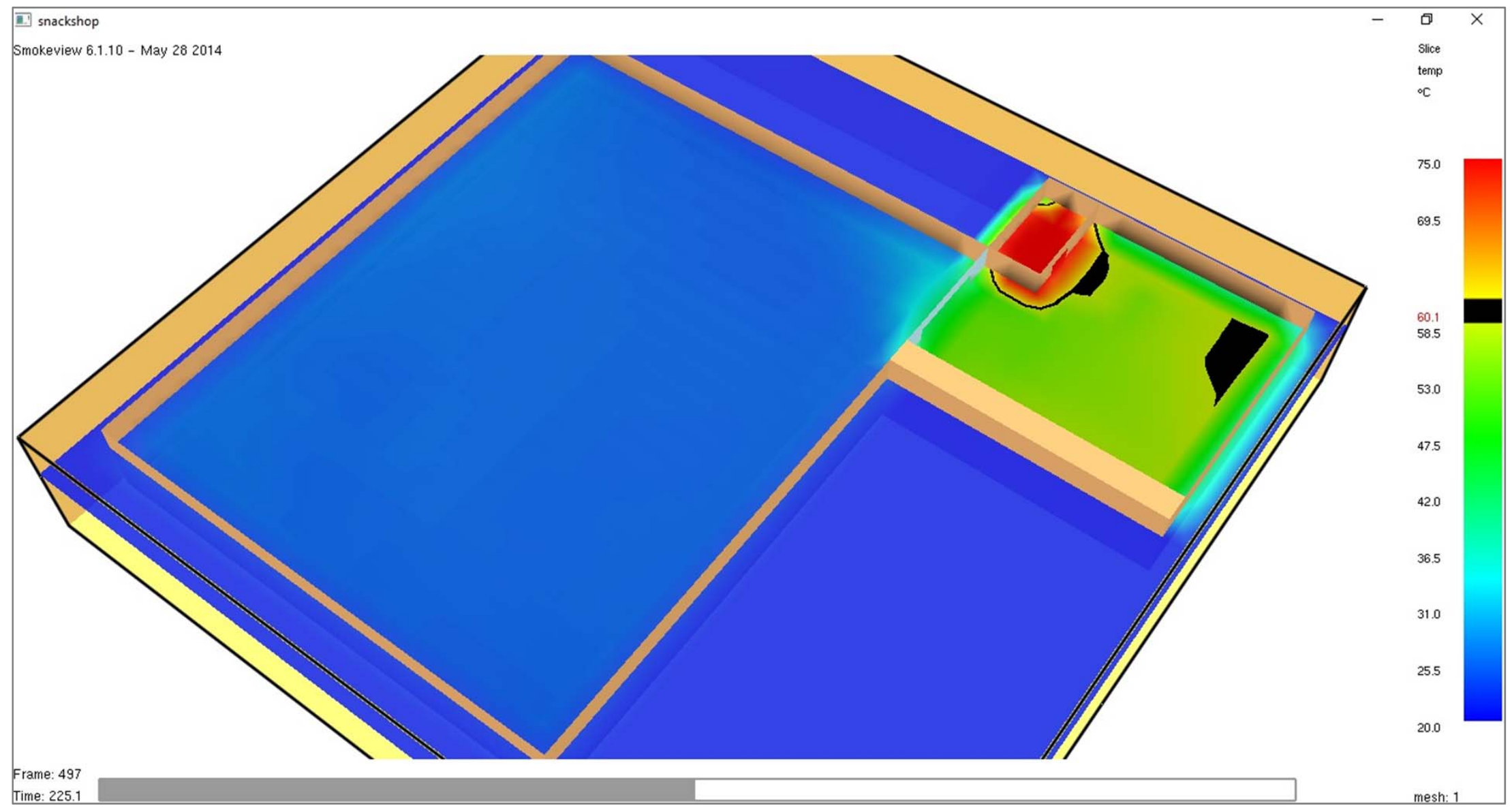

- Temperature at RSET (158 seconds) 


\section{Fire Scenario 2}

ASET Vs RSET

\section{ASET/RSET - Convenience Store Fire}

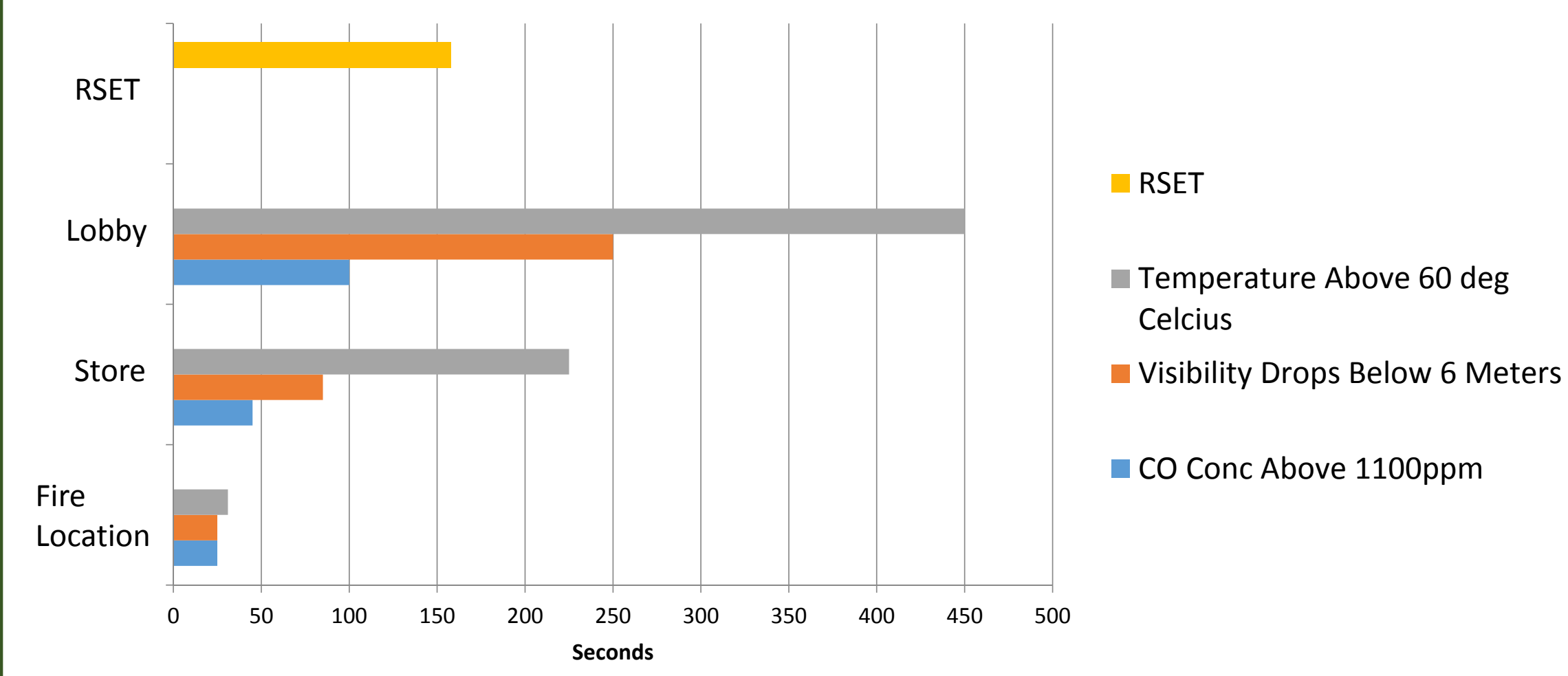




\section{Fire Scenario 2}

Summary

- Small office/storage room

- All conditions fail rapidly

- Store

- Assumption is that personnel evacuate the store as they activate the pull station at 45 seconds

- This is also when CO concentrations begin to enter the store area

- Lobby

- CO concentration is the limiting factor for the lobby

- Does not become widespread until well past RSET 


\section{Fire Scenario 2}

Recommendations

- Same as Scenario 1

- Install smoke detectors in the space to try to reduce detection, alarm, and notification times and therefore reducing evacuation time

- Use the HVAC system to purge smoke and toxic gases in the event of a fire 


\section{Questions}

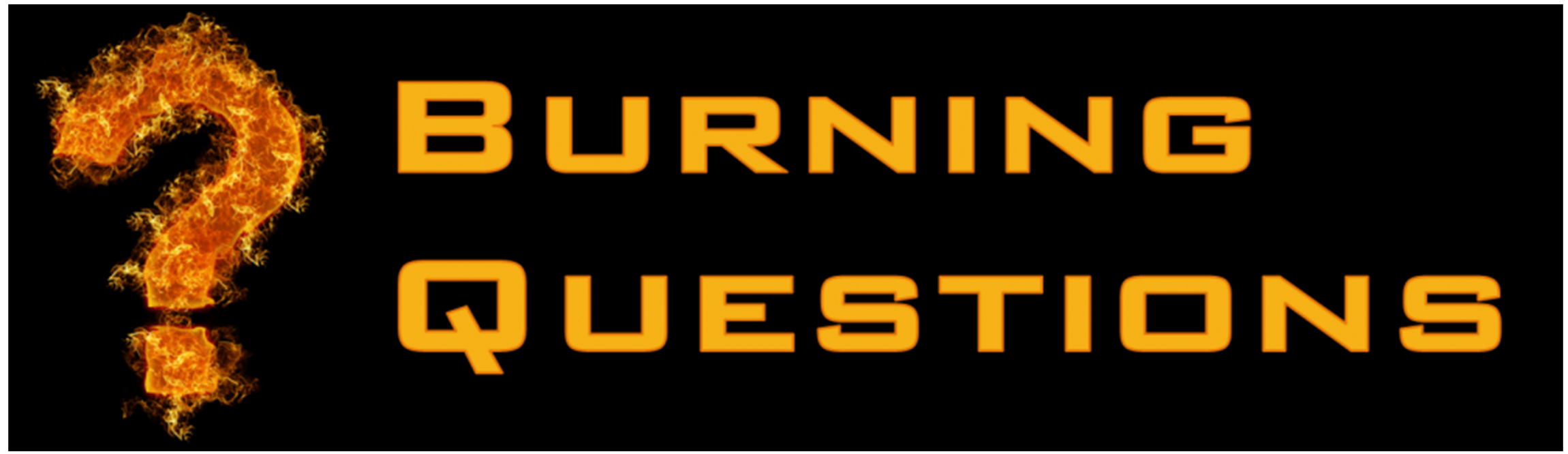

